\title{
Phylogeny and historical biogeography of Silky Lacewings (Neuroptera: Psychopsidae)
}

Authors: DEON K. BAKKES ${ }^{* 1,2}$, MERVYN W. MANSELL ${ }^{1}$, CATHERINE L. SOLE $^{1}$ *ORCID ID: 0000-0002-5716-0801

Affiliation: ${ }^{1}$ Department of Zoology and Entomology, University of Pretoria, Private Bag X 20, 0028, Hatfield, South Africa.

Present address: ${ }^{2}$ Gertrud Theiler Tick Museum, Epidemiology, Parasites \& Vectors, Agricultural Research Council - Onderstepoort Veterinary Research, Pretoria, 0110, South Africa

Running title: Silky Lacewing Evolution

Correspondence: $\quad{ }^{1}$ Deon Bakkes and ${ }^{2}$ Catherine Sole

Department of Zoology and Entomology,

University of Pretoria,

Private Bag X 20, 0028, Hatfield, South Africa.

Email: ${ }^{1}$ seventiaguitarist@gmail.com, ${ }^{2}$ clsole@zoology.up.ac.za

Phone: +27 124203236 


\section{Graphical Abstract}

Highlight 1: Afrotropical Silveira represent an entirely unique lineage that warrants placement in its own subfamily.

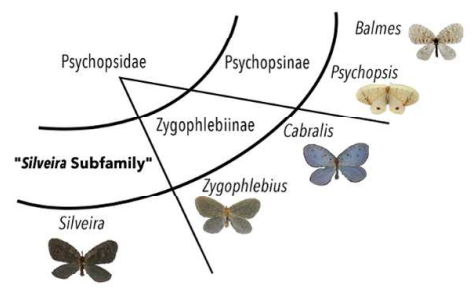

Highlight 2: Current worldwide distribution resulted from vicariance events associated with Gondwanaland breakup, wherein India moved extant Balmes to their present day location in south-east Asia.

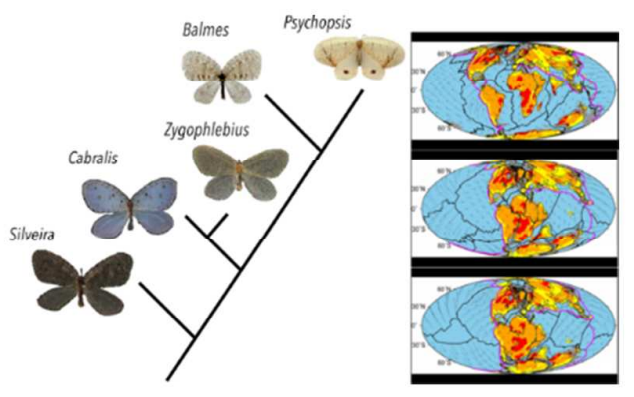

Highlight 3: Divergences between Afrotropical species are hypothesized as driven by adaptations to either arid or moist climates and associated habitat types.

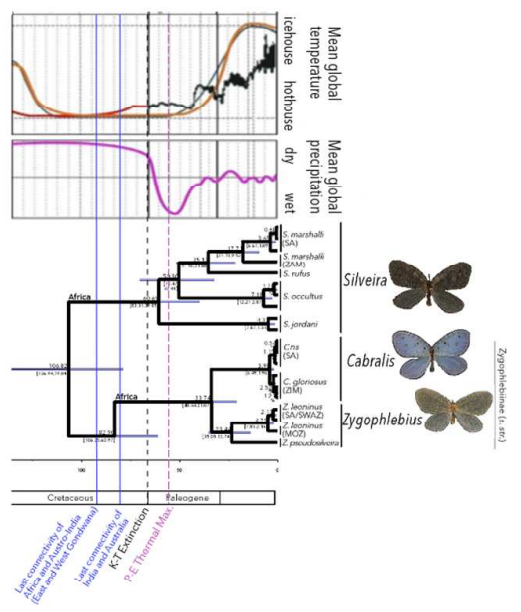




\section{Abstract}

Psychopsidae (silky winged lacewings) are a small family of Neuroptera characterised by broad hirsute wings that impart a physical resemblance to moths. The fossil record includes many psychopsid-like taxa from the Late Triassic to Early Oligocene from all major continents. Extant species have a disjunct, tripartite distribution comprising Afrotropical, south-east Asian and Australian regions that is significant to historical biogeography. Two subfamilies are currently recognized: Zygophlebiinae in the Afrotropics, and Psychopsinae in Australia and south-east Asia. This study explores phylogeny and historical biogeography of Psychopsidae, using data from biogeography, comparative morphology and molecular sequences (16S, 18S, CAD, COI). Our results show that (1) the morphological phylogeny is incongruent with molecular data, (2) Afrotropical Silveira Navás, represent a separate lineage that warrants placement in its own subfamily, (3) the family originated in Pangea, and (4) the present genus level distribution resulted from two vicariance events associated with Gondwanan fragmentation.

Key words: Afrotropical, Lacewing, Phylogenetics, Ancestral area, Molecular phylogeny, Morphology, Neuroptera.

\section{Introduction}

Psychopsidae Handlirsch (Neuroptera) are a small family of lacewings, comprising about 26 extant species in five genera worldwide (Oswald, 1993). Members are characterized by broad moth-like wings with a parallel triplet-vein formation comprising the subcostal, radial and radial sector veins collectively known as the vena triplica. Extant species manifest a disjunct, tripartite distribution between the Afrotropical, Australian and south-east Asian regions. The Afrotropical fauna (Figs 1A, B, C, D, G, H) comprises three genera: Cabralis Navás; Silveira Navás and Zygophlebius Navás in Zygophlebiinae Navás, while Australian and south-east Asian fauna have only one genus each: Psychopsis Newman in Australia and Balmes Navás in south-east Asia, both in Psychopsinae Handlirsch. Larvae have been found in leaf debris surrounding trees, and two Australian species are known to live under bark of myrtaceous trees, preying on Microlepidoptera (Tillyard, 1919b; Tjeder, 1960). Adult females have a specialized oviposition strategy that involves grinding a substrate of sand or plant material with the toothed side of the gonocoxite stylus. The substrate is then transferred to the abdominal chamber and used to coat eggs, probably for camouflage and minimizing desiccation. Eggs are laid singly during flight (Tjeder, 1960; New, 1988; Oswald, 1993). 


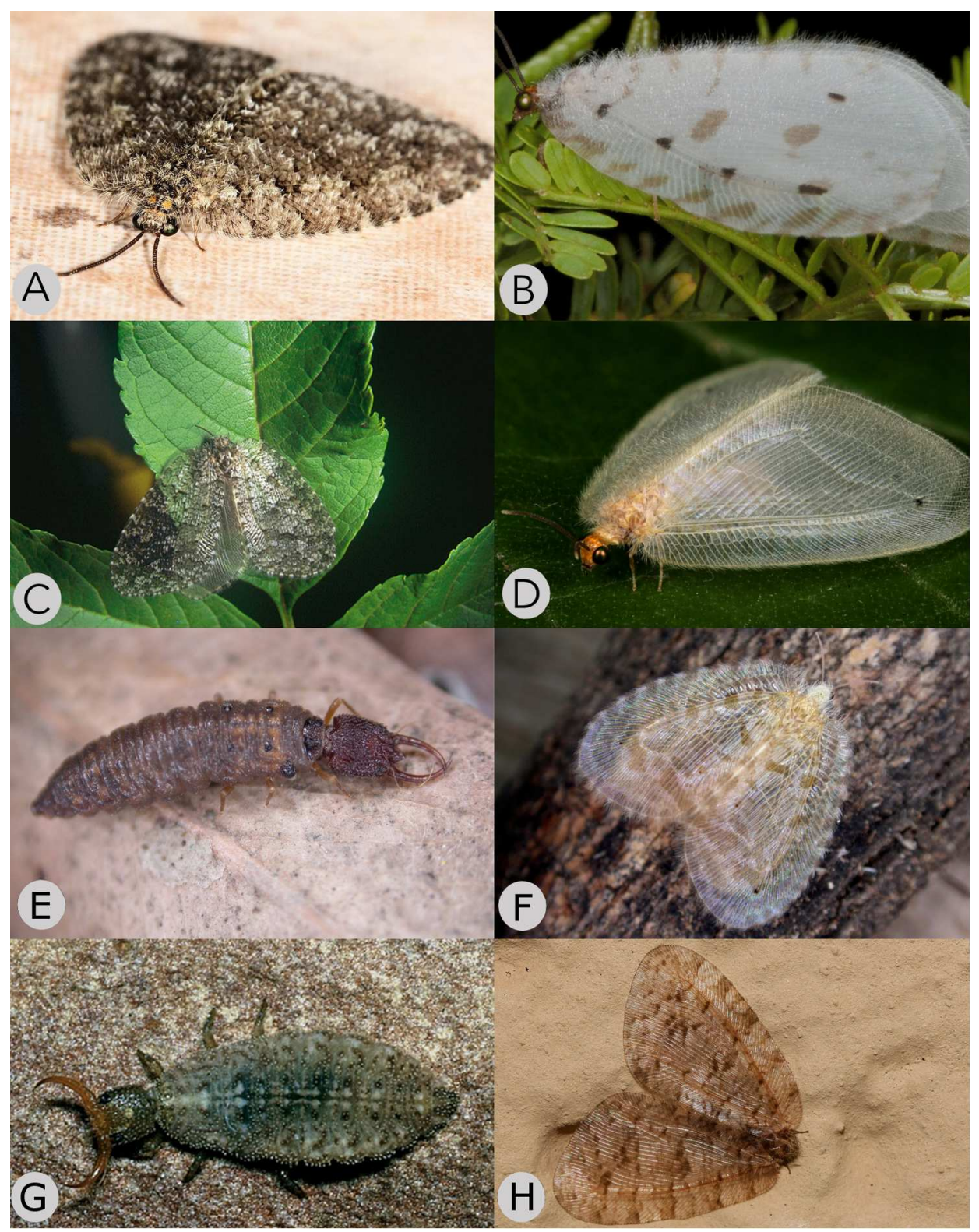

Figure 1. Diversity of Psychopsidae. A) Silveira marshalli (McLachlan, 1902) (Photo: Wynand Uys). B) Cabralis cns (Photo: Hennie de Klerk). C) Silveira occultus Tjeder, 1960 (Photo: Peter Duelli). D) Zygophlebius leoninus Navás, 1910 (Photo: Wynand Uys). E) Psychopsis sp. Larva (Photo: Shaun Winterton). F) Psychopsis insolens (Photo: Shaun Winterton). G) Cabralis cns larva (Photo: Peter Duelli). H) Silveira rufus (Photo: Penni Warncke).

$627 \times 796 \mathrm{~mm}(72 \times 72 \mathrm{DPI})$ 
Fossil Psychopsidae manifest considerable disparity across a rich fossil record. The Kalligrammatidae Handlirsch, Aetheogrammatidae Ren \& Engel and Osmylopsychopidae Martynova (syn. Brongniartiellidae Martynova; see Peng et al. 2016) are extinct families that share the closest relationship with extant Psychopsidae (Fig. 2 and Andersen, 2001). Makarkin (2010) placed these within Psychopsoidea Handlirsch which, in turn, is sister to Myrmeleontiformia (Withycombe, 1925; Mansell, 1992; Haring \& Aspöck, 2004; Grimaldi \& Engel, 2005; Beutel \& Pohl, 2006; Badano et al., 2016). Psychopsidae (s. str.) comprise fossil Triassopsychopsinae Tillyard along with extant taxa, and are considered a distinct lineage of Psychopsoidea united by a broad costal space (Makarkin, 1997; Andersen, 2001; Lambkin, 2014). Within Psychopsidae (s. str.), extant lineages have an abruptly closing vena triplica distally, while extinct Baisopsychops Makarkin and Triassopsychops Tillyard (Triassopsychopsinae) have this termination gradually tapering (Fig. 2). This supports division between all extant subfamilies, and extinct Triassopsychopsinae (Tillyard, 1922b; Makarkin, 1997; Andersen, 2001). Fossil Propsychopsis Krüger are an exception with a tapering vena triplica similar to Triassopsychops, but with similar adult characters to extant Balmes (MacLeod, 1970), and similar larval characters to extant Psychopsis (Tillyard, 1919a; MacLeod, 1970). These similarities place Propsychopsis near Balmes in Psychopsinae (Andersen, 2001).

Psychopsidae have previously been considered close related to, or the sister family of Nemopteridae Burmeister based on assessments of adult and larval morphology (Withycombe 1925; Aspöck et al. 2001). Recent studies however, which focused holistically on Neuropterida using molecular and morphological characters, have shown that Psychopsidae are closer to Nymphidae Rambur, placing Psychopsidae as sister to all other Myrmeleontiformia (Winterton et al., 2010; Wang et al., 2016). Extant species are divided into Zygophlebiinae and Psychopsinae based on a cladistic analysis of 60 morphological characters (Oswald, 1993). Psychopsinae comprise Australian and south-east Asian genera that appear closely related despite geographic distance (New, 1988; Oswald, 1993). Zygophlebiinae comprise all Afrotropical genera, with Cabralis and Zygophlebius closely related, and Silveira more pleisiomorphic and distinct (Oswald, 1993).

Historical biogeography of extant Psychopsidae was investigated by Oswald (1993) in an area cladogram test (Nelson \& Platnick, 1981; Humphries \& Parenti, 1986) that was formulated to account for Balmes in south-east Asia. This test found most support for an Australian dispersal route based on the close relationship between Balmes and Psychopsis, and indicated that Balmes underwent north-western dispersal from Australia along the Malay Archipelago to mainland Asia. The second most-supported hypothesis was Indian drift, postulating that Balmes arrived in south-east Asia via tectonic movement of India towards 


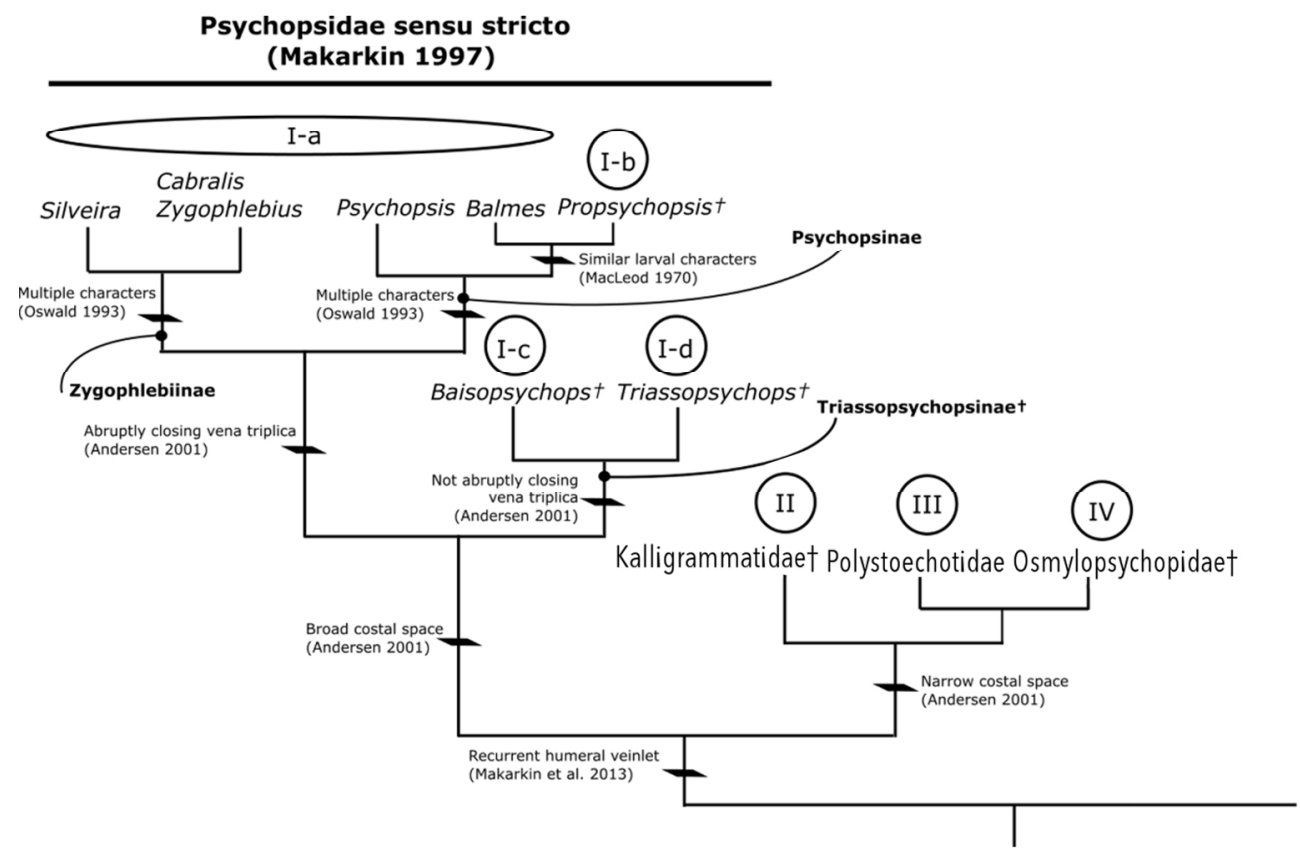

Figure 2. Cladogram of Psychopsoidea taxa including fossils, based on the text of Andersen (2001). Groups I-IV follow Andersen (2001) and represent relatedness to extant Psychopsidae (Group I-a).

Synapomorphies explained in the text are shown uniting each clade with relevant literature cited. +

$160 \times 103 \mathrm{~mm}(300 \times 300$ DPI) 
Asia after Gondwanaland fragmented (Ali \& Aitchison, 2008). Oswald (1993) also considered hypotheses for Balmes as a Laurasian relic and an African disperser, but these were rejected due to the close relationship between Balmes and Psychopsis (Oswald, 1993). This delimited Psychopsidae historical biogeography under two competing hypotheses. Uncertainty remains however, due to the limitation of not including timing data in the areacladogram test (Oswald, 1993).

The aim of this study was to estimate phylogenetic relationships among extant Psychopsidae species and genera with reference to their historical biogeography. We tested the current taxonomy of the family using integrated morphological and molecular data. Secondly, vicariance or dispersal at each phylogenetic node was tested using estimates of divergence time and ancestral area based on extant distribution patterns. Proposed explanations for each divergence were sought in correlates of paleogeography, historical climate and habitat change.

\section{Material and methods}

\section{Sampling and taxon selection}

Taxa used in this study are listed alongside voucher and GenBank accession numbers in Supplementary Table S1. Twenty-three Psychopsidae specimens were collected either by hand-netting or at mercury vapour light traps, preserved in absolute ethanol and placed into $20^{\circ} \mathrm{C}$ storage. Sequences for Psychopsis margarita Tillyard were obtained from Genbank. The sample-set represents all extant genera and all major biogeographic regions of Psychopsidae. Afrotropical species were sampled extensively although fresh material of Zygophlebius zebra (Brauer) was not collected. Australian and south-east Asian faunas were represented by two species from each genus. Nine outgroup taxa were selected based on the phylogeny of Winterton et al. (2010) according to sister clade sampling (Hillis, 1998). The final dataset comprised 33 individuals representing thirteen Psychopsidae species. Specimens collected by the authors are housed in the South African National Collection of Insects, Pretoria (SANC) with accession numbers from the Palpares Relational Database (Mansell \& Kenyon, 2002) as voucher numbers (Table S1).

\section{Morphological characters}

Ninety-eight morphological characters describing adult morphology of males and females were scored for phylogenetic analyses (Table S2). These characters include Oswald's (1993) dataset, although several were refined to improve states specific to Afrotropical taxa. 
New characters specific to Afrotropical species were added. All morphological characters were treated as unordered, with gap or unknown characters coded as "-" or "?" respectively.

DNA extraction, sequencing and alignment

Four genes were selected for sequencing to represent a range of mutational rate changes over time, maximizing phylogenetically informative data, and testing whether gene trees reflect the species tree by congruence (Doyle, 1992; Maddison, 1997; Nichols, 2001). These comprised two ribosomal genes (16S rDNA and $18 \mathrm{~S}$ rDNA) and two protein-encoding genes (mitochondrial cytochrome oxidase I; COI, and nuclear CPSase region of carbamoylphosphate synthetase-aspartate transcarbamoylase-dihydroorotase; CAD).

Two legs were removed from each specimen for genomic DNA extraction using the Macherey-Nagel NucleoSpin ${ }^{\circledR}$ Tissue kit (Düren, Germany). Previously published primer sequences were used to amplify genomic DNA was amplified in polymerase chain reactions (PCR) (Table S3). PCR mixtures were prepared to a final volume of either $50 \mu \mathrm{L}$ or $25 \mu \mathrm{L}$ containing $2.5 \mathrm{mM} \mathrm{MgCl}_{2}$, 20pmol of each primer, $10 \mathrm{mM}$ dNTPs, 1 x PCR buffer, with 1 unit of TaqDNA polymerase (Supertherm ${ }^{\circledR}$ DNA polymerase, Separation Scientific SA (Pty) Ltd, South Africa; or Emerald Amp®MAX HS PCRMastermix, Takara Bio Inc., Otsu, Shiga, Japan) in the presence of 100-500ng of extracted genomic DNA template. Cycling parameters varied for each gene (Table S3). Successful amplifications were purified using the Macherey-Nagel NucleoSpin $®$ Gel and PCR Clean-up kit (Düren, Germany). Cycle sequencing reactions in both sequence directions used the BigDye® Terminator v3.1 Cycle Sequencing kit (Applied Biosystems, Foster City, USA). All sequences were viewed, assembled and edited in CLC Bio main Workbench Version 6.9 (http://www.clcbio.com). New sequences were submitted to GenBank (Table S1).

Alignments of edited sequences were estimated for each gene region based on primary structure (nucleotide bases) using MAFFT online (Katoh et al., 2005; Katoh \& Toh, 2008). The online tool was instructed to employ the 'Auto' strategy for alignment, inspect direction of nucleotide sequences and adjust according to the first sequence. Subsequently, the aligned sequences were inspected visually.

\section{Phylogenetic analyses}

A 50\% reciprocal bootstrap test (Mason-Gamer \& Kellogg, 1996; Reeb et al., 2004) of the four gene partitions was conducted in PAUP*4.0b10 (Swofford, 2003) under maximum parsimony. This tested whether the four genetic datasets (16S, 18S, COI, CAD) showed congruence and could be combined. Neighbour network trees for ingroup taxa were 
constructed in SplitsTree v4.14.3 (Huson \& Bryant, 2006) to test the same assumption. Analyses were performed on the morphological and concatenated-molecular datasets separately, with trees inspected for congruence. Thereafter, combined molecular and morphological analyses were performed. Morphological, concatenated-molecular, and combined morphology/molecular datasets were analyzed under maximum parsimony in PAUP*4.0b10 (Swofford, 2003). The concatenated-molecular dataset and combined morphology/molecular dataset were analyzed under maximum likelihood in RAxML-HPC v8.1.20 (Stamatakis, 2014), and under Bayesian inference in MrBayes v3.2.5 (Ronquist \& Huelsenbeck, 2003). Appropriate models for base pair substitution rates were estimated in jModel Test v2.1.6 (Posada, 2008) under the Akaike information criterion (Table S4).

Parsimony analyses employed heuristic tree search. All characters were equally weighted and unordered, uninformative characters excluded. A starting tree was obtained with the tree-bisection-reconnection (TBR) branch swapping algorithm using 10 replicates of random stepwise addition of sequences. Initial 'maxtrees' was set to 200 with automatic increase by 100. Bootstrap support values (Felsenstein, 1985) were calculated from heuristic search using TBR branch swapping pseudoreplicated in 1000 resampled datasets with simple addition of 10 sequences. Maximum likelihood analyses employed separate nucleotide substitution models for each partition with empirical base frequencies for each model estimated in RAxML-HPC. An unordered MK model for multistate characters was applied to the morphological partition. Bootstrap support was based on 1000 pseudoreplicates and was followed by thorough maximum likelihood search. Analysis was repeated five times, using different starting seeds to sample tree space effectively. Analyses used the rapid hill climbing algorithm (Stamatakis et al., 2007). Bayesian inference was done using nucleotide substitution models selected by jModel Test for each gene (Table S4). Parameters for each partition were unlinked to obtain separate estimates, with rate prior set as variable from a flat Dirichlet distribution. Analysis was run by two Monte-Carlo-Markov-Chains ( $\left.\mathrm{MC}^{2}\right)$ simultaneously for 30 million iterations sampling every $200^{\text {th }}$ iteration, resulting in 150000 trees. The first 37500 (25\%) trees from each $M^{2} C^{2}$ run were discarded as burn-in. Analysis was repeated, and all four runs were combined to produce a majority rule consensus tree with posterior probabilities at each node. Tracer v1.6 (Drummond \& Rambaut, 2007) was used to assess convergence and sampling efficiency between runs. All ESS values were greater than 200 indicating effective sampling (Drummond et al., 2006).

\section{Divergence time estimates}

Divergence times were estimated in BEAST v2.1.2 (Bouckaert et al., 2014) using the concatenated-molecular dataset. A relaxed molecular clock was modelled under an 
uncorrelated lognormal model with the Yule speciation process applied. Yule speciation assumes a pure birth process, but with branch length distribution similar to birth-death processes, and an equivalent net birth rate. Separate substitution models were used for each partition (Table S4) with model and clock parameters unlinked across all partitions. Analyses were set to 300 million iterations, with every $1000^{\text {th }}$ iteration sampled. A starting tree was generated from random seed. Analysis was run four times to ensure effective sampling. The first 75000 (25\%) trees from each run were discarded as burn-in. Apart from node age constraints, default settings were used for all priors. LogCombiner v2.1.2 (Bouckaert et al., 2014) was used to combine log and tree outputs from the four independent runs. Tracer assessed convergence and sampling efficiency between runs, with all ESS values greater than 200, indicating effective sampling. TreeAnnotator v2.1.2 (Bouckaert et al., 2014) generated the maximum clade credibility tree and calculated node ages with $\pm 95 \%$ High Posterior Density (HPD) confidence intervals.

Fossil dates from published literature served as calibrations (Table 1). Four outgroup nodes and two ingroup nodes were calibrated, each modelled under lognormal prior distributions to allow priors to serve as minimum age constraints, and vary towards including older divergence times. Each distribution was modelled with an offset, mean and standard deviation that set $95 \%$ of priors within minimum and maximum ages of fossil dates. The minimum age constraint on the most recent common ancestor (MRCA) of the ingroup (node A, Table 1) was set to the Late Triassic based on Triassopsychops superbus Tillyard (237$228 \mathrm{Mya})$, and was calibrated as a stem with a wide interval of priors to allow analyses to optimize divergence time estimates, rather than adhere to hard constraints. Uncertainty in phylogenetic placement and possibility of extinction in Psychopsidae motivated this decision (Fig. 2). The approximately 20 My difference between first appearances of Triassopsychops, and the estimated divergence time of extant Psychopsis (Winterton et al. 2010), is probably due to the crown node of Psychopsis being younger than the stem node of Psychopsis + Triassopsychops (Fig. 2). This makes divergence time recovered by Winterton et al. (2010) attributable to the later divergence of extant Psychopsidae from the rest of Myrmeleontiformia, instead of to the earlier divergence between Myrmeleontiformia and Triassopsychopsinae (as Psychopsidae stem).

\section{Ancestral areas}

Ancestral area probabilities were estimated in RASP v3.2 (Yu et al., 2015) to test whether vicariance or dispersal was dominant, and which ancestral area per node was most likely. Evolutionary events were inferred as either dispersal, vicariance, extinction or standard speciation; the last serves as a null hypothesis that makes cladogenesis clock like (Kuhner \& 
Table 1. Fossil taxon information and prior distribution parameters for divergence time analysis.

\begin{tabular}{|c|c|c|c|c|c|c|c|c|}
\hline \multirow[b]{2}{*}{ Constraint } & \multirow[b]{2}{*}{$\begin{array}{l}\text { Most recent common } \\
\text { ancestor (MRCA) }\end{array}$} & \multirow{2}{*}{$\begin{array}{l}\text { Fossil [geological } \\
\text { period; } \\
\text { age }(\mathrm{Ma}) \text { ] }\end{array}$} & \multirow[b]{2}{*}{ References } & \multicolumn{5}{|c|}{ Prior distribution parameters } \\
\hline & & & & $\begin{array}{l}\text { Prior } \\
\text { distribution }\end{array}$ & Offset & $\begin{array}{l}\text { Log } \\
\text { (mean) }\end{array}$ & $\begin{array}{l}\log \\
(\mathrm{SD})\end{array}$ & $\begin{array}{l}95 \% \mathrm{CI} \\
\text { of priors }\end{array}$ \\
\hline A & Psychopsidae (ingroup) & $\begin{array}{l}\text { Triassopsychops } \\
\text { superbus Tillyard } \\
\text { (1922b) [Late Triassic } \\
\text { (Carnian); } 237 \text { to 228] }\end{array}$ & $\begin{array}{l}\text { Tillyard (1922b), Peng } \\
\text { et al. }(2011) \text { and } \\
\text { Lambkin (2014) }\end{array}$ & Lognormal & 205 & 2.2 & 0.7 & $207.3-240.6$ \\
\hline B & $\begin{array}{l}\text { B. birmanus }+ \\
\text { B. terissinus }\end{array}$ & $\begin{array}{l}\text { Propsychopsis lapcidae } \\
\text { MacLeod (1970) } \\
\text { [Eocene; } 54.8 \text { to 33.7] }\end{array}$ & MacLeod (1970) & Lognormal & 30 & 2.2 & 0.5 & $33.4-54.0$ \\
\hline $\mathrm{C}$ & Apochrysa + Notiobiella & $\begin{array}{l}\text { Lembochrysa miniscula } \\
\text { Ren \& Guo (1996) } \\
\text { [Late Jurassic; 160] }\end{array}$ & $\begin{array}{l}\text { Ren \& Guo (1996) and } \\
\text { Nel et al. }(2005)\end{array}$ & Lognormal & 160 & 1.7 & 0.5 & $162.1-174.6$ \\
\hline $\mathrm{D}$ & Polystoechotes + Ithone & $\begin{array}{l}\text { Jurapolystoechotes } \\
\text { melanolomusi Ren, } \\
\text { Engel \& Lü (2002) } \\
\text { [Middlie Jurassic; } \\
\text { 170] }\end{array}$ & Ren et al. (2002) & Lognormal & 170 & 1.5 & 0.6 & $171.4-184.5$ \\
\hline $\mathrm{E}$ & Libelloides + Ululodes & $\begin{array}{l}\text { Choromyrmeleon } \\
\text { othneius Ren \& Guo } \\
\text { (1996) [Late Jurassic; } \\
\text { 150] }\end{array}$ & Ren \& Guo (1996) & Lognormal & 149 & 1.5 & 0.5 & $151.0-161.0$ \\
\hline $\mathrm{F}$ & Nymphes + Osmylops & $\begin{array}{l}\text { Nymphes georgei } \\
\text { Archibald, Makarkin } \\
\text { \& Ansorge (2009) } \\
\text { [Early Eocene; } \\
\text { 49.96-48.88] }\end{array}$ & Archibald et al. (2009) & Lognormal & 48 & 1.2 & 0.6 & $49.0-58.0$ \\
\hline
\end{tabular}


Felsenstein, 1994). A dataset of 15000 trees obtained from BEAST was used, and was pruned to exclude duplicate representatives and distantly related outgroup taxa to minimize unequal taxon bias. However, Notiobiella Banks (Hemerobiidae) and Apochrysa Schneider (Chrysopidae) were kept to provide deep resolution. The dataset was analyzed under two models of ancestral area estimation: S-DIVA (Yu et al., 2010) and BayArea (Landis et al., 2013). Parameters for each analysis are presented in Table S5. Areas were assigned to biogeographic regions of extant Psychopsidae: (A) Australia, (B) south-eastern Africa, (C) south-western Africa, and (D) south-eastern Asia. Combined area codes represent historical landmasses such as Gondwanaland (ABCD) and Austro-India (AD).

\section{Results}

Phylogenetic analyses

Morphological characters (90 parsimony informative) analyzed under parsimony yielded 156 equally most parsimonious trees (length $=160$ steps, consistency index $(\mathrm{Cl})=0.8125$, retention index $(R I)=0.9506)$. The strict consensus tree of bootstrap support greater than $50 \%$ is presented in Supplementary Fig. S1A. The three Afrotropical genera, Cabralis, Zygophlebius and Silveira, were monophyletic (bootstrap support $=87 \%$ ), with Cabralis recovered as sister to Zygophlebius with limited support (68\%). Cabralis comprised two species, C. gloriosus Navás (87\%) sister to an undescribed species, 'Cns' (Oswald, 1993) $(58 \%)$. Silveira was monophyletic $(100 \%)$ with the following six synapomorphies: (1) Presence of three ocellar/cranial pulvinae (character 1), (2) Male sternite IX narrow or parallel-sided (character 29: Table S2), (3) Female $9^{\text {th }}$ gonocoxite with longitudinal row of stiff setae (character 83), (4) Female $9^{\text {th }}$ gonocoxite with suprastylar setae $<50 \%$ cochleariform (character 86), (5) Female $9^{\text {th }}$ gonocoxite with stylus bearing sharp, long spines (character 88), and (6) Female spermatheca with ventral lobes narrow in lateral view (character 93). Within Silveira, S. jordani Kimmins was recovered as sister to the rest of the genus $(100 \%)$, and $S$. rufus Tjeder was recovered as sister to $S$. occultus Tjeder $+S$. marshalli (McLachlan) (94\%). Silveira occultus was sister to S. marshalli (98\%), and monophyly of S. marshalli was likewise well supported (91\%).

Sequence data yielded a total of 3746 nucleotide base pair characters after alignment. Model parameters and sequence information for each gene partition is summarized in Table S4. The $50 \%$ reciprocal bootstrap test and neighbour network trees for the four gene partitions showed congruence with major clades always present, confirming the assumption of phylogenetic congruence (Figs S1, S2: Supplementary material). Consequently, individual gene data were combined. Molecular data analyzed under parsimony yielded a single most 
parsimonious tree (length $=3193$ steps, $\mathrm{Cl}=0.5011, \mathrm{RI}=0.6756$ ). The strict $50 \%$ consensus tree is presented in Fig. S3B alongside the morphological tree, highlighting incongruence. Parsimony analysis of the combined morphology/molecular dataset yielded one most parsimonious tree (length $=3355$ steps, $\mathrm{Cl}=0.5156, \mathrm{RI}=0.7055$ ). Maximum likelihood analyses recovered a single best tree, congruent with parsimony and Bayesian trees of the combined morphology/molecular data. This indicates that adding information from morphology to molecular data did not alter phylogenetic relationships, but marginally increased parsimony support for monophyly of ((Balmes + Psychopsis) + (Cabralis + Zygophlebius)) (parsimony bootstrap $=84 \%$ from combined data versus $80 \%$ from molecular data alone, see Figs 3 and S3B). The Bayesian consensus tree with posterior probability and bootstrap support is shown in Fig. 3. Bootstrap values of greater than $70 \%$, and posterior probability values greater than 0.95, are considered strong support (Hillis \& Bull, 1993; Rannala \& Yang, 1996; Erixon et al., 2003). Nodes were considered strongly supported when good support was received from at least two out of three analyses (Sheldon \& Bledsoe, 1993; Miyamoto \& Fitch, 1995).

Combined morphological and molecular data analyzed under parsimony, maximum likelihood and Bayesian inference recovered the family as monophyletic (parsimony bootstrap $=100 \%$, maximum likelihood bootstrap $=100 \%$, Bayesian posterior probability $=1$; Fig. 3). Zygophlebiinae s. lat. (Cabralis, Zygophlebius and Silveira), was recovered as paraphyletic. Cabralis + Zygophlebius were monophyletic $(100 \%, 100 \%, 1)$, and Balmes + Psychopsis (i.e. Psychopsinae) were also monophyletic but with limited support (64\%, 59\%, 0.88). The node comprising ((Cabralis + Zygophlebius $)+($ Psychopsis + Balmes $))$ was recovered with good support $(84 \%, 65 \%, 0.99)$. Silveira was recovered as monophyletic, sister to ((Cabralis + Zygophlebius) + (Psychopsis + Balmes $))(100 \%, 100 \%, 1)$. Within Silveira, S. jordani was monophyletic $(100 \%, 100 \%, 1)$, sister to the rest of the genus. Silveira occultus was monophyletic $(100 \%, 100 \%, 1)$ and was sister to the monophyletic $S$. rufus + S. marshalli $(71 \%, 100 \%, 0.99)$.

\section{Divergence time estimates}

The maximum clade credibility tree was congruent with parsimony, maximum likelihood and Bayesian trees from combined morphology/molecular and concatenated-molecular data. The divergence time estimates tree is shown in Fig. 4 with generally narrow 95\% HPD intervals, indicating confidence in estimates.

Psychopsidae are estimated to have diverged from the rest of Neuroptera in the Late Triassic, 214 Mya (95\% HPD interval = 224.50-206.17 Mya). Silveira diverged from the remaining Psychopsidae in the Mid Cretaceous about 107 Mya (136.94-79.04 Mya) and 


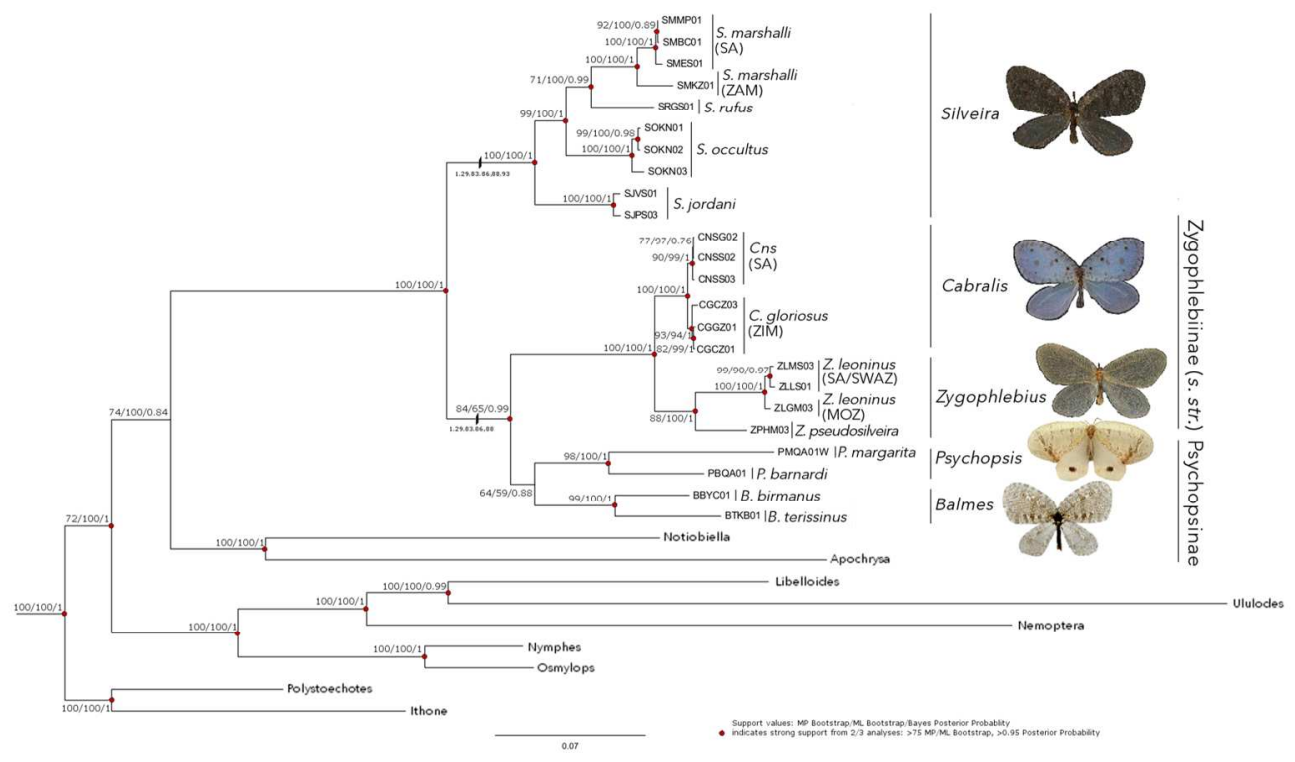

Figure 3. Bayesian consensus tree recovered from Bayesian analysis of combined morphological/ molecular dataset. Bootstrap values from parsimony and maximum likelihood, as well as Bayesian posterior probabilities are displayed above nodes (MP/ML/Bayesian). Red nodes indicate strong support from at least two out of three analyses i.e. $>70 \%$ bootstrap for parsimony and maximum likelihood, and $>0.95 \%$ posterior probability for Bayesian analysis. Dashes with corresponding numbers on Silveira and Zygophlebiinae (s. str.) + Psychopsinae lineages refer to morphological synapomorphies for these lineages - numbers refer to characters in the morphological dataset (Table S2: supplementary material). Uppercase codes refer to specimen country of collection (MOZ - Mozambique, SA - South Africa, SWAZ - Swaziland, ZAM - Zambia, ZIM - Zimbabwe). Photo credits: Psychopsis - Graeme Cocks, Balmes - Hao Huang, Silveira, Cabralis and Zygophlebius - Deon Bakkes.

$180 \times 108 \mathrm{~mm}(300 \times 300$ DPI $)$ 


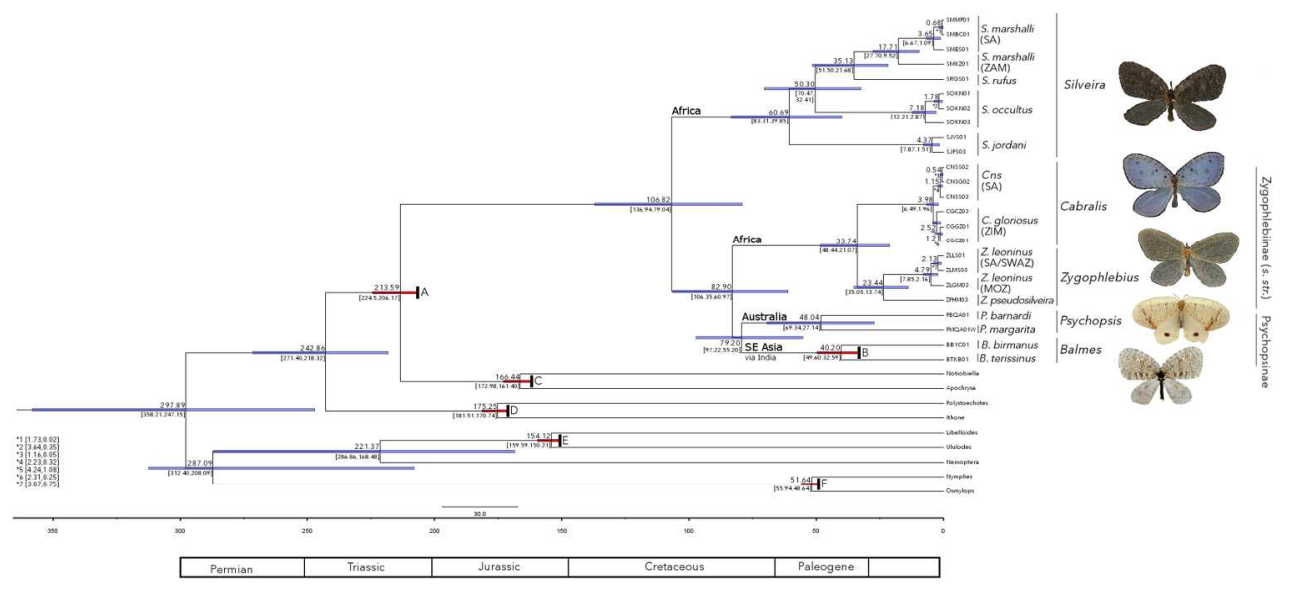

Figure 4. Divergence time estimates for Psychopsidae from analyses of the concatenated molecular dataset (16S, 18S, CAD, COI). Median node ages are displayed above nodes. 95\% high posterior density (HPD) intervals are displayed in [] brackets below nodes and are represented by blue bars transecting each node. *HPD intervals in the bottom-left refer to those that were unable to fit below the node. Red nodes A, $B, C, D, E$ and $F$ are constrained based on relevant fossils for those taxa, discussed in the text. Time-scale units are in millions of years.

$180 \times 83 \mathrm{~mm}(300 \times 300 \mathrm{DPI})$ 
underwent a series of radiations in the Late Cretaceous to Oligocene/Early Miocene about 61-35 Mya (83.31-21.68 Mya from combined 95\% HPD). The Cabralis + Zygophlebius lineage diverged from the Balmes + Psychopsis lineage in the Mid to Late Cretaceous about 83 Mya (106.35-60.97 Mya), with Balmes and Psychopsis diverging from one another soon after at about 79 Mya (97.22-55.20 Mya). Cabralis and Zygophlebius diverged in the Eocene/Oligocene at 34 Mya (48.44-21.07 Mya). Cabralis gloriosus and Cns diverged in the Late Miocene/Pliocene, about 4 Mya (6.49-1.96 Mya).

\section{Ancestral areas}

Ancestral areas are summarized in Fig. 5 with probability charts of each model at each node, and dispersal-vicariance-extinction plots juxtaposed with the phylogeny. Plots were similar with the exception of a single extinction event in BayArea modelling. Dispersal was estimated to be dominant in deeper time (130-80 Mya) with vicariance playing a role more recently (90-40 Mya).

Psychopsidae are estimated to have originated in Gondwanaland, somewhere between Australia and parts of Africa (Fig. 5). Divergence of Silveira occurred in Gondwanaland by dispersal. Silveira subsequently underwent a series of divergences in Africa, the earliest two (S. jordani and S. occultus) were between south-east and south-west Africa (standard speciation). The Cabralis + Zygophlebius lineage diverged from the Balmes + Psychopsis lineage in Gondwanaland (between south-east Africa, Australia and south-east Asia), by a combination of standard speciation, vicariance and dispersal. Balmes and Psychopsis diverged in a similar manner (Fig. 5), however this result is contentious because node frequency is low (46\%). This indicates limited taxon sampling and highlights the need for increased sampling of these genera.

\section{Discussion}

Psychopsidae were supported as being monophyletic and sister to the rest of Myrmeleontiformia (Fig. 3) in line with previous studies (Withycombe, 1925; Oswald, 1993; Aspöck et al., 2001; Winterton et al., 2010; Badano et al., 2016; Wang et al. 2016). This suggests they form an entirely separate clade of Myrmeleontiformia, and if fossil Psychopsoidea are monophyletic (Makarkin, 2010; Makarkin et al., 2013; Peng et al. 2016), then Psychopsidae represent the last remnant of fossil rich Psychopsoidea. Within Psychopsidae, Zygophlebiinae including Silveira (Zygophlebiinae s. lat.), are considered monophyletic (Oswald, 1993), but our results indicate paraphyly. Incongruence between morphological and molecular data manifests in Afrotropical genera and between Silveira species (Fig. S3). Morphology recovered Silveira in Zygophlebiinae (s. lat.), but Silveira fell 


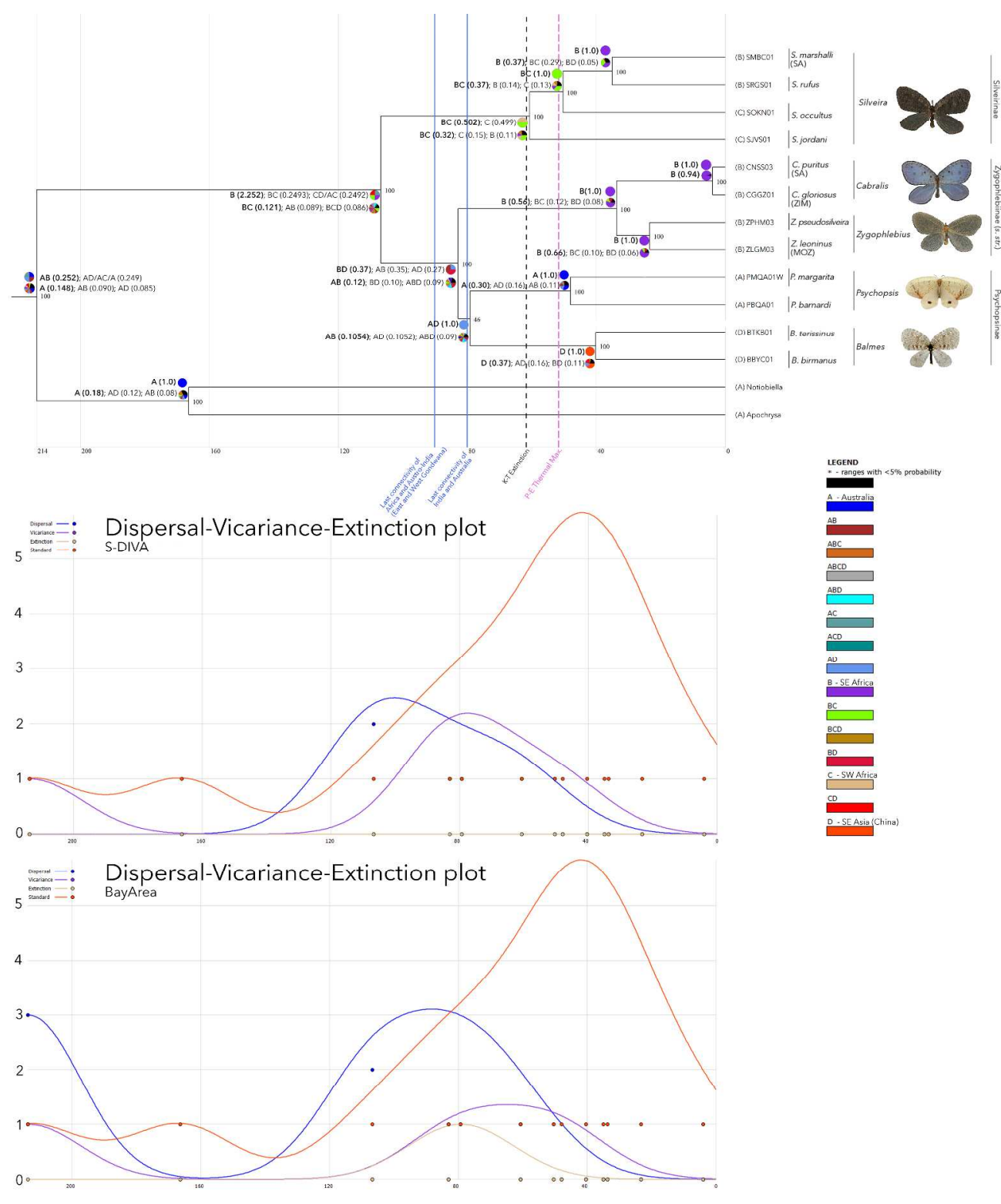

Figure 5. Ancestral area estimation of 15000 BEAST trees. Statistics left of each node represent results from two models (top-to-bottom: S-DIVA and BayArea). Pie charts represent probabilities for ancestral area by colour. Text alongside each pie chart represents the probabilities of the three or four mostsupported ancestral areas for the model, at that node. Ancestral area with best support per model is bolded at a given node. Mass extinction events are represented by black dashed lines, climatic events by purple dashed lines, and dates of last faunal connectivity between landmasses by solid blue lines. DisperalVicariance-Extinction plots from S-DIVA and BayArea analyses are juxtaposed with the ancestral area estimation phylogeny. Time-scale units are in millions of years and the $y$-axis represents inferred events.

$491 \times 576 \mathrm{~mm}(300 \times 300 \mathrm{DPI})$ 
significantly beyond the Cabralis + Zygophlebius (Zygophlebiinae s. str.) clade when molecular data were analyzed (Figs 3, S3B). This demonstrates that Silveira comprise a separately evolving lineage that warrants placement in a new subfamily. Revisiting morphology yields synapomorphies to support this (branch dashes in Fig. 3), and Tjeder (1960) considered Silveira basal, leaving a close relationship between Cabralis, Nothopsychops Tillyard ([sic.] synonym of Zygophlebius) and Psychopsis. His assertions were based on similar synapomorphies as highlighted here (Fig. 3).

The disjunct, tripartite distribution of extant Psychopsidae is significant to their historical biogeography, suggesting Gondwanan origin (Tillyard, 1919a). However, the earliest fossil, T. superbus, appears in the Carnian (220.7-227.4 Mya; Denmark Hill, Queensland, Australia) before Pangea fragmented (ca. 160 Mya) (Scotese, 2004; Schettino \& Turco, 2009; Seton et al., 2012). This study reveals that Psychopsidae diverged approximately 214 Mya (224.5-206.17 Mya; Fig. 4; corroborating Winterton et al., 2010), pre-dating fragmentation of Pangea into Gondwanaland and Laurasia (ca. 180 Mya: Seton et al., 2012). This supports the contention that Psychopsidae were widespread during the Mesozoic and inhabited most of Pangea during their radiation (Oswald, 1993; Anderson, 2001). Fossil Baisopsychops from Laurasia in the Cretaceous corroborate this, but these form a lineage separate from extant taxa considering wing vein morphology (Andersen, 2001). This indicates extant Psychopsidae may have been restricted to southern Gondwanaland producing the present distribution. Alternatively, extinction of all lineages in Laurasia may explain the present distribution apparently Gondwanan as derived. Indeed, the CretaceousPaleogene (K-Pg) extinction might have significantly decreased Psychopsidae abundance, especially in Laurasia (Makarkin \& Archibald, 2014).

Dispersal and vicariance seem prevalent at different stages of psychopsid historical biogeography. Dispersal was generally dominant before Gondwanan fragmentation, with vicariance prevalent during fragmentation, and a combination of these two processes evident later (Fig. 5). Divergence of Silveira occurred at 107 Mya (136.94-79.04 Mya; Fig. 4) within African parts of Gondwanan, probably by dispersal (Fig. 5). This pre-dates last faunal connectivity between Africa and Austro-India at about 90 Mya and conclusively excludes vicariance (Bossuyt et al., 2006). Zygophlebiinae (s. str.) in the Afrotropics and Psychopsinae in Australasia suggests Gondwanan vicariance. Their divergence occurred at 83 Mya (106.35-60.97 Mya, Fig. 4) in Gondwanan, concurring with last faunal connectivity between Africa and Australia, putatively indicating vicariance (Jokat, 2003; Scotese, 2004; Bossuyt et al., 2006; Seton et al., 2012). Dispersal is possible however, because 95\% HPD (maximum age at 106.35 Mya; Fig. 4) encompasses up to 16 My before last faunal 
connectivity was lost. Nonetheless, Gondwanan vicariance provides a reasonable explanation given the majority of estimates after this time.

Historical biogeography of Balmes can be narrowed to two possibilities (Oswald, 1993). Either dispersal from Australia along the Malay Archipelago, or vicariance with Indian drift after Austro-India fragmented. The former requires divergence time between Psychopsis and Balmes correlating with Malay Archipelago formation (ca. 25 Mya: Scotese, 2004; Seton et al., 2012), while the latter requires such correlation with Austro-India fragmentation instead (ca. 80 Mya: Scotese, 2004; Bossuyt et al., 2006; Ali \& Aitchison, 2008; Seton et al., 2012). This divergence occurred at 79 Mya (97.22-55.20 Mya, Fig. 4), which significantly pre-dates Malay Archipelago formation and approximates last faunal connectivity between India and Australia. This conclusively excludes Australian dispersal. This finding is corroborated by mitochondrial phylogenomics of Wang et al. (2016) with divergence time of Psychopsis at 99 Mya (204.26-43.66 Mya), although based on a different species. MacLeod (1970) speculated Psychopsis underwent prolonged and isolated evolution based on morphology. Indian drift supports such isolation. However, timing estimates again have 95\% HPD up to $17 \mathrm{My}$ before last faunal connectivity between India and Australia (maximum age limit at 97.22 Mya; Fig. 4 ), indicating a small chance of dispersal. Nonetheless, strong rejection of Australian dispersal from timing demonstrates that Balmes drifted on India toward mainland Asia.

Propsychopsis fossils that are closely related to Balmes based on morphological similarity (MacLeod, 1970; Andersen, 2001) provide additional clues for Balmes historical biogeography. These fossils are only known from Priabonian Baltic amber (37.2-33.9 Mya) (Peng et al., 2011), which post-dates the India-Asia collision (ca. 55 Mya: Zhu et al., 2005; Aitchison, et al. 2007; Ali \& Aitchison, 2008; Seton et al., 2012). This suggests Propsychopsis diverged from Balmes before the Eocene, became isolated in India, and similarly underwent Indian drift to reach Asia. Alternatively, tropical faunas were widespread at this time due to hot-house temperatures; hence Propsychopsis may be explained by Laurasian endemism. However, this seems unlikely given striking morphological similarity with Balmes, and the lack of Propsychopsis at other psychopsid rich fossil deposits before this time. Similar cases of putative Indian drift are found in fossil Ceratopogonidae (Diptera) of Cambay amber (55-52 Mya; Gujarat, India) that imply faunal exchange between India, Asia and Europe in the Early Eocene (Stebner et al., 2017), as well as in extant Thyridosmylus Krüger (Osmylidae) that have sister species in Madagascar and south-east Asia, suggesting a close biogeographic connection (Wang et al., 2011). India as a 'biotic ferry' has also been proposed for frogs and Eocene mammals (Bossuyt \& Milinkovitch, 2001; Thewissen et al., 2010). 
An undescribed species of Cabralis (Cns) was confirmed as sister to C. gloriosus (Fig. 3), corroborating Oswald (1993). Cabralis gloriosus is restricted to Afromontane forests in the eastern Zimbabwean highlands, and Cns to Afromontane forests in the Soutpansberg mountains of South Africa. Allopatric speciation is hypothesized following fragmentation of Eocene forests. Divergence between C. gloriosus and Cns occurred 4 Mya (6.49-1.96 Mya; Fig. 4) in south-east Africa. Little support for either vicariance or dispersal was available (Fig. 5), although compelling evidence from disjunct distributions support vicariance. Climatically, this divergence closely post-dates decreasing global precipitation (Frakes, 1979), and coincides with final stages of Afromontane forest fragmentation (Axelrod \& Raven, 1978; White, 1981; Lovett, 1988; Burgoyne et al., 2005). This would have split presumably widespread Cabralis progenitors between respective Afromontane refugia, resulting in allopatric speciation. Another case of sister species in Afromontane refugia from a similar period is found in bats of the east African mountains (Taylor et al., 2012).

Regarding relationships among Silveira species, morphology and molecular data were incongruent. Morphology places S. jordani and S. rufus as closely related, alongside a monophyletic S. occultus + S. marshalli (Fig. S3A) (Oswald 1993). However, molecular data place S. jordani and S. occultus as sister instead, with S. rufus + S. marshalli monophyletic (Figs S3B, 3). Molecular data accords with distribution patterns between groups on western (S. jordani + S. occultus) and eastern (S. rufus + S. marshalli) sides of the continent, and these distribution patterns mirror those of arid adapted plants (Jürgens, 1997) as well as Myrmeleontidae (Mansell, 1990). Divergence of S. jordani from the MRCA of (((S. occultus) + S. rufus) + S. marshalli) occurred at 61 Mya (83.31-39.85 Mya; Fig. 4), and divergence of S. occultus from the MRCA of S. rufus + S. marshalli occurred at 50 Mya (70.47-32.41 Mya; Fig. 4), both between south-west and south-east Africa. Timing coincides with climatic flux between arid and moist climates globally (Frakes, 1979), initiated by the Paleocene-Eocene Thermal Maximum (PETM; Wing et al. 2005). This stimulated forest expansion (Maley, 1996; Jacobs, 2004) and subsequently radiation of $\mathrm{C}_{4}$ grasses characteristic of savannah and woodland habitats (Cerling et al., 1997; Jacobs, 2004; Mannetje, 2007). Such evidence contends that during the Eocene, Afrotropical arid biomes gave way to forest expansion with the south-west coast remaining dry (Rayner et al., 1991; Tankard \& Rogers, 1978). Progenitors of $S$. jordani would have diverged from the MRCA of $(((S$. occultus $)+S$. rufus $)+$ S. marshalli) following climatic and habitat change. 


\section{Conclusion}

This study represents a comprehensive treatment of Psychopsidae evolutionary history that integrates morphological, molecular and biogeographic data. The main findings indicate that traditional morphological data are generally incongruent with molecular data, resulting in paraphyly of Zygophlebiinae (s. lat.). Afrotropical Silveira represent a divergent lineage of extant Psychopsidae. Cabralis and Zygophlebius (Zygophlebiinae s. str.) in the Afrotropics are monophyletic, and sister to Australasian Psychopsinae. Divergence time estimation and historical biogeography supports Psychopsidae origin in Pangea, and suggests that the present disjunct, tripartite distribution resulted from Gondwanaland vicariance and Indian drift. Beyond this, evolution of Afrotropical lineages were probably driven by adaptations to moist and arid habitats with associated expansions and contractions.

\section{Acknowledgements}

The authors extend special thanks to Werner Strümpher for his patience and assistance as a mentor in many aspects of the work. Thanks to the following persons for their invaluable aid in sampling, or providing fresh specimens for molecular analysis: Philip Rousseau (R.I.P.), Louwtjie Snyman, Nina Parry, Obety Baptista, Dorothy Madamba, Shaun Winterton, John Oswald, Xingyue Liu, Simon van Noort, Sasha Hoffman and Arné Verhoef. John Oswald is especially thanked for his insightful review and comments on an earlier draft of the work. Clarke Scholtz and the Scarab Research Group, University of Pretoria, are thanked for providing the environment in which this study could take place. Funding for this work was provided by the National Research Foundation (NRF), the Research and Development funding body at the University of Pretoria and the JRS Biodiversity Foundation, U.S.A.

\section{References}

Aitchison, J.C., Ali, J.R. \& Davis, A.M. (2007) When and where did India and Asia collide?. Journal of Geophysical Research, 112, 1-19.

Ali, J.R. \& Aitchison, J.C. (2008) Gondwana to Asia: Plate tectonics, paleogeography and the biological connectivity of the Indian sub-continent from the Middle Jurassic through latest Eocene (166-35 Ma). Earth-Science Reviews, 88, 145-166.

Andersen, S. (2001) Silky lacewings (Neuroptera: Psychopsidae) from the EocenePaleocene transition of Denmark with a review of the fossil record and comments on phylogeny and zoogeography. Insect Systematics and Evolution, 32, 419-438.

Archibald, S.B., Makarkin, V.N. \& Ansorge, J. (2009) New fossil species of Nymphidae (Neuroptera) from the Eocene of North America and Europe. Zootaxa, 68, 59-68.

Aspöck, U. \& Aspöck, H. (2008) Phylogenetic relevance of the genital sclerites of Neuropterida (Insecta: Holometabola). Systematic Entomology, 33, 97-127. 
Aspöck, U., Plant, J. \& Nemeschkal, H. (2001) Cladistic analysis of Neuroptera and their systematic position within Neuropterida (Insecta: Holometabola: Neuropterida: Neuroptera). Systematic Entomology, 26, 73-86.

Axelrod, D.I. \& Raven, P.H. (1978) Late Cretaceous and Tertiary vegetation history of Africa. In: M. J. A. Werger (Ed), Biogeography and ecology of southern Africa. Dr W. Junk bv Publishers, The Hague, 77-130.

Badano, D., Aspöck, U., Aspöck, H. \& Cerretti, P. (2016) Phylogeny of Myrmeleontiformia based on larval morphology (Neuropterida: Neuroptera). Systematic Entomology, 42, 94117.

Beutel, R.G. \& Pohl, H. (2006) Endopterygote systematics - where do we stand and what is the goal (Hexapoda, Arthropoda)?. Systematic Entomology, 31, 202-219.

Bossuyt, F., Brown, R.M., Hillis, D.M., Cannatella, D.C. \& Milinkovitch, M.C. (2006) Phylogeny and biogeography of a cosmopolitan frog radiation: Late cretaceous diversification resulted in continent-scale endemism in the family Ranidae. Systematic Biology, 55, 579-594.

Bossuyt, F. \& Milinkovitch, M.C. (2001) Amphibians as Indicators of Early Tertiary "Out-ofIndia" Dispersal of Vertebrates. Science, 292, 93-95.

Bouckaert, R., Heled, J., Kühnert, D., Vaughan, T., Wu, C.-H., Xie, D., Suchard, M.A., Rambaut, A. \& Drummond, A.J. (2014) BEAST 2: a software platform for Bayesian evolutionary analysis. PLoS Computational Biology, 10, e1003537.

Brauer, F. (1889) Beitrag zur Kenntniss der Psychopsis-Arten. Annalen des KK Naturhistorischen Hofmuseums, Wien, 4, 101-103.

Burgoyne, P.M., van Wyk, A.E., Anderson, J.M. \& Schrire, B.D. (2005) Phanerozoic evolution of plants on the African plate. Journal of African Earth Sciences, 43, 13-52.

Burmeister, H. (1839) Handbuch der Entomologie. Enslin, Berlin, 757-1050.

Cerling, T.E., Harris, J.M., Macfadden, B.J., Leakey, M.G., Quade, J., Eisenmann, V. \& Ehleringer, J.R. (1997) Global vegetation change through the Miocene/Pliocene boundary. Nature, 389, 153-158.

Doyle, J.J. (1992) Gene Trees and Species Trees: Molecular Systematics as One-Character Taxonomy. Systematic Botany, 17, 144-163.

Drummond, A.J., Ho, S.Y.W., Phillips, M.J. \& Rambaut, A. (2006) Relaxed phylogenetics and dating with confidence. PLoS Biology, 4, 699-710.

Drummond, A.J. \& Rambaut, A. (2007) BEAST: Bayesian evolutionary analysis by sampling trees. BMC Evolutionary Biology, 7, 214.

Erixon, P., Svennblad, B., Britton, T. \& Oxelman, B. (2003) Reliability of Bayesian Posterior Probabilities and Bootstrap Frequencies in Phylogenetics. Systematic Biology, 52, 665-673. 
Felsenstein, J. (1985) Confidence Limits on Phylogenies: An Approach Using the Bootstrap. Evolution, 39, 783-791.

Frakes, L.A. (1979) Climates throughout geologic time. Elsevier, Amsterdam, 1-304.

Grimaldi, D. \& Engel, M.S. (2005) Evolution of the Insects. Cambridge University Press, Cambridge, 1-763.

Handlirsch, A. (1906) Die fossilen Insekten und die Phylogenie der rezenten formen. W. Engelmann, Leipzig, 1-1430.

Haring, E. \& Aspöck, U. (2004) Phylogeny of the Neuropterida: a first molecular approach. Systematic Entomology, 29, 415-430.

Hillis, D.M. (1998) Taxonomic Sampling, Phylogenetic Accuracy, and Investigator Bias. Systematic Biology, 47, 3-8.

Hillis, D.M. \& Bull, J.J. (1993) An empirical test of bootstrapping as a method for assessing confidence in phylogenetic analysis. Systematic Biology, 42, 182-192.

Humphries, C.J. \& Parenti, L.R. (1986) Cladistic Biogeography. Clarendon Press, Oxford, 1200.

Huson, D.H. \& Bryant, D. (2006) Application of phylogenetic networks in evolutionary studies. Molecular Biology and Evolution, 23, 254-267.

Jacobs, B.F. (2004) Palaeobotanical studies from tropical Africa: relevance to the evolution of forest, woodland and savannah biomes. Philosophical transactions of the Royal Society of London. Series B, Biological sciences, 359, 1573-83.

Jokat, W. (2003) Timing and geometry of early Gondwana breakup. Journal of Geophysical Research, 108, 2428.

Jürgens, N. (1997) Floristic biodiversity and history of African arid regions. Biodiversity and Conservation, 6, 495-514.

Katoh, K., Kuma, K., Toh, H. \& Miyata, T. (2005) MAFFT version 5: improvement in accuracy of multiple sequence alignment. Nucleic acids research, 33, 511-8.

Katoh, K. \& Toh, H. (2008) Recent developments in the MAFFT multiple sequence alignment program. Briefings in Bioinformatics, 9, 286-98.

Krüger, L. (1913) Osmylidae. Beiträge zu einer Monographie der Neuropteren-familie der Osmylidae. Stettiner Entomologische Zeitung, 74, 1-122.

Krüger, L. (1923) Neuroptera succinica baltica. Die im baltischen Bernstein eingeschlossenen Neuropteren des Westpreußischen Provinzial - Museums (heute Museum für Naturkunder und Vorgeschichte) in Danzig. Stettiner Entomologische Zeitung, 84, 68-92.

Kuhner, M.K. \& Felsenstein, J. (1994) A simulation comparison of phylogeny algorithms under equal and unequal evolutionary rates. Molecular Biology and Evolution, 11, 459-468. 
Lambkin, K.J. (2014) Psychopsoid Neuroptera (Psychopsidae, Osmylopsychopidae) from the Queensland Triassic. The Australian Entomologist, 41, 57-76.

Landis, M.J., Matzke, N.J., Moore, B.R. \& Huelsenbeck, J.P. (2013) Bayesian analysis of biogeography when the number of areas is large. Systematic Biology, 62, 789-804.

Lovett, J.C. (1988) Endemism and affinities of the Tanzanian montane forest flora. In: P. Goldblatt and P. P. Lowry (Eds), Monographs in Systematic Botany from the Missouri Botanical Garden, 25, 591-598.

MacLeod, E.G. (1970) The Neuroptera of the Baltic amber. I. Ascalaphidae, Nymphidae, and Psychopsidae. Psyche, 77, 147-180.

Maddison, W.P. (1997) Gene Trees in Species Trees. Systematic Biology, 46, 523-536.

Makarkin, V.N. (1991) Miocene Neuroptera from North Caucasus and Sikhote-Alin. Paleontologicheskii Zhurnal, 1, 57-68.

Makarkin, V.N. (1997) Fossil Neuroptera of the Lower Cretaceous of Baisa, East Siberia. Part 4: Psychopsidae. Beiträge zur entomologie, 47, 489-492.

Makarkin, V.N. (2010) New psychopsoid Neuroptera from the Early Cretaceous of Baissa, Transbaikalia. Annales de la Société Entomologique de France, 46, 254-261.

Makarkin, V.N. \& Archibald, S.B. (2014) An unusual new fossil genus probably belonging to the Psychopsidae (Neuroptera) from the Eocene Okanagan Highlands, western North America. Zootaxa, 3838, 385-391.

Makarkin, V.N., Yang, Q., Shi, C. \& Ren, D. (2013) The presence of the recurrent veinlet in the Middle Jurassic Nymphidae (Neuroptera): a unique character condition in Myrmeleontoidea. ZooKeys, 20, 1-20.

Maley, J. (1996) The African rain forest - main characteristics of changes in vegetation and climate from the Upper Cretaceous to the Quaternary. Proceedings of the Royal Society of Edinburgh. Section B. Biological Sciences, 104B, 31-73.

Mannetje, L. 't (2007) Climate change and grasslands through the ages: an overview. Grass and Forage Science, 62, 113-117.

Mansell, M.W. (1990) Biogeography and relationships of southern African Myrmeleontidae (Insecta: Neuroptera). In: M. Mansell and H. Aspock (Eds), Advances in Neuropterology. Proceedings of the Third International Symposium on Neuropterology. (3-4 February 1988, Berg en Dal, Kruger National Park, South Africa). South African Department of Agricultural Development, Pretoria, 181-190.

Mansell, M.W. (1992) The systematic position of Nemopteridae (Insecta: Neuroptera: Myrmeleontoidea). In: M. Canard, H. Aspöck, and M. W. Mansel (Eds), Current Research in Neuropterology. Proceedings of the Fourth International Symposium on Neuropterology, Bagneres-de-Luchon, Haute-Garonne, France. 24-27 June 1991. Private publisher, Toulouse, France, 233-241. 
Mansell, M.W. \& Kenyon, B. (2002) The Palpares Relational Database: An Integrated Model for Lacewing Research. Acta Zoologica Academiae Scientiarum Hungaricae, 48, 185-195.

Martynova, O.M. (1949) Mesozoic lacewings (Neuroptera) and their bearing on concepts of phylogeny and systematics of the order. Trudy Paleontologicheskogo Instituta, 20, 150-170.

Mason-Gamer, R.J. \& Kellogg, E.A. (1996) Testing for Phylogenetic Conflict Among Molecular Data Sets in the Tribe Triticeae (Gramineae). Systematic Biology, 45, 524-545.

Miyamoto, M.M. \& Fitch, W.M. (1995) Testing Species Phylogenies and Phylogenetic Methods with Congruence. Systematic Biology, 44, 64-76.

Navás, L. (1910) Hemeróbidos (Ins. Neur.) nuevos con la clave de las tribus y géneros de la familia. Brotéria (Zoologica), 9, 69-90.

Navás, L. (1912)a) Crisópidos Y Hemeróbidos (Ins. Neur.) neuvos ó críticos. Brotéria (Zoologica), 10, 98-113.

Navás, L. (1912)b) Insectos neurópteros nuevos o poco conocidos. Memorias de la Real Academia de Ciencias y Artes de Barcelona, 10, 135-202.

Nel, A., Delclos, X. \& Hutin, A. (2005) Mesozoic chrysopid-like Planipennia: a phylogenetic approach (Insecta: Neuroptera). Annales de la Société Entomologique de France, 41, 2968.

Nelson, G. \& Platnick, N.I. (1981) Systematics and biogeography: Cladistics and Vicariance. Columbia University Press, New York, 1-567.

New, T. (1988) The Psychopsidae (Insecta: Neuroptera) of Australia and the Oriental Region. Invertebrate Taxonomy, 2, 841-883.

Newman, E. (1842) Entomological Notes. Entomologist, 1, 413-415.

Nichols, R. (2001) Gene trees and species trees are not the same. Trends in Ecology \& Evolution, 16, 358-364.

Oswald, J.D. (1993) Phylogeny, taxonomy, and biogeography of extant silky lacewings (Insecta: Neuroptera: Psychopsidae). Memoirs of the American Entomological Society, 40, $1-65$.

Peng, Y., Makarkin, V.N., Wang, X. \& Ren, D. (2011) A new fossil silky lacewing genus (Neuroptera, Psychopsidae) from the Early Cretaceous Yixian Formation of China. ZooKeys, 228, 217-28.

Peng, Y., Makarkin, V.N. \& Ren, D. (2016) Diverse new Middle Jurassic Osmylopsychopidae (Neuroptera) from China shed light on the classification of Psychopsoids. Journal of Systematic Paleontology, 14, 261-295.

Posada, D. (2008) jModelTest: phylogenetic model averaging. Molecular Biology and Evolution, 25, 1253-6.

Rambur, P. (1842) Histoire naturelle des insectes: Névroptères. Roret, Paris, 1-534. 
Rannala, B. \& Yang, Z. (1996) Probability Distribution of Molecular Evolutionary Trees: A New Method of Phylogenetic Inference. Journal of Molecular Evolution, 43, 304-311.

Rayner, R.J., Waters, S.B., McKay, I.J., Dobbs, P.N. \& Shaw, A.L. (1991) The MidCretaceous palaeoenvironment of central Southern Africa (Orapa, Botswana).

Palaeogeography, Palaeoclimatology, Palaeoecology, 88, 147-156.

Reeb, V., Lutzoni, F. \& Roux, C. (2004) Contribution of RPB2 to multilocus phylogenetic studies of the euascomycetes (Pezizomycotina, Fungi) with special emphasis on the lichenforming Acarosporaceae and evolution of polyspory. Molecular Phylogenetics and Evolution, 32, 1036-60.

Ren, D., Engel, M.S. \& Lü, W. (2002) New Giant Lacewings from the Middle Jurassic of Inner Mongolia, China (Neuroptera: Polystoechotidae). Journal of the Kansas Entomological Society, 75, 188-193.

Ren, D. \& Engel, M.S. (2008) Aetheogrammatidae, A New Family of Lacewings from the Mesozoic of China (Neuroptera: Myrmeleontiformia). Journal of the Kansas Entomological Society 81:161-167.

Ren, D. \& Guo, Z. (1996) On the new fossil genera and species of Neuroptera (Insecta) from the late Jurassic of Notheast China. Acta Zootaxonomica Sinica, 21, 461-479.

Ronquist, F. \& Huelsenbeck, J.P. (2003) MrBayes 3: Bayesian phylogenetic inference under mixed models. Bioinformatics, 19, 1572-1574.

Schettino, A. \& Turco, E. (2009) Breakup of Pangaea and plate kinematics of the central Atlantic and Atlas regions. Geophysical Journal International, 178, 1078-1097.

Scotese, C.R. (2004) A Continental Drift Flipbook. Journal of Geology, 112, 729-741.

Seton, M., Müller, R.D., Zahirovic, S., Gaina, C., Torsvik, T., Shephard, G., Talsma, a., Gurnis, M., Turner, M., Maus, S. \& Chandler, M. (2012) Global continental and ocean basin reconstructions since 200Ma. Earth-Science Reviews, 113, 212-270.

Sheldon, F.H. \& Bledsoe, A.H. (1993) Avian Molecular Systematics, 1970s to 1990s. Annual Review of Ecology and Systematics, 24, 243-278.

Stamatakis, A. (2014) RAxML version 8: a tool for phylogenetic analysis and post-analysis of large phylogenies. Bioinformatics, 30, 1312-3.

Stamatakis, A., Blagojevic, F., Nikolopoulos, D.S. \& Antonopoulos, C.D. (2007) Exploring New Search Algorithms and Hardware for Phylogenetics: RAxML Meets the IBM Cell. The Journal of VLSI Signal Processing Systems for Signal, Image, and Video Technology, 48, 271-286.

Swofford, D.L. (2003) Phylogenetic analysis using parsimony (* and other methods). Version 4. Sinauer associates, Sunderland, MA.

Tankard, A.J. \& Rogers, J. (1978) Late Cenozoic palaeoenvironments on the west coast of southern Africa. Journal of Biogeography, 5, 319-337. 
Taylor, P.J., Stoffberg, S., Monadjem, A., Schoeman, M.C., Bayliss, J. \& Cotterill, F.P.D. (2012) Four new bat species (Rhinolophus hildebrandtii complex) reflect Plio-Pleistocene divergence of dwarfs and giants across an Afromontane archipelago. PloS one, 7, e41744.

Thewissen, J.G.M., Williams, E.M. \& Hussain, S.T. (2010) Eocene mammal faunas from northern Indo-Pakistan. Journal of Vertebrate Paleontology, 21, 347-366.

Tillyard, R.J. (1919)a) Studies in Australian Neuroptera. No. 6. The Family Psychopsidae, with Descriptions of New Genera and Species. Proceedings of the Linnean Society of New South Wales, 43, 750-786.

Tillyard, R.J. (1919)b) Studies in Australian Neuroptera. No. 7. The Life-History of Psychopsis elegans (Guérin). Proceedings of the Linnean Society of New South Wales, 43, 787-814.

Tillyard, R.J. (1922)a) Descriptions of two new Australian species of Psychopsis. Australian Zoologist, 3, 35-38.

Tillyard, R.J. (1922)b) Mesozoic Insects of Queensland. No. 9. Orthoptera, and Additions to the Protorthoptera, Odonata, Hemiptera, and Planipennia. Proceedings of the Linnean Society of New South Wales, 47, 447-470.

Tjeder, B. (1960) Neuroptera-Planipennia. The Lace-wings of Southern Africa. 3. Family Psychopsidae. In: B. Hanström, P. Brinck, and G. Rudebec (Eds), South African Animal Life. Swedish Natural Science Research Council, Stockholm, 164-209.

Wang, Y., Liu, X., Garzón-Orduña, I.J., Winterton, S.L., Yan, Y., Aspöck, U., Aspöck, H. \& Yang, D. (2016) Mitochondrial phylogenomics illuminates the evolutionary history of Neuropterida. Cladistics, 32, 1-20.

Wang, Y., Winterton, S.L. \& Liu, Z. (2011) Phylogeny and biogeography of Thyridosmylus (Neuroptera: Osmylidae). Systematic Entomology, 36, 330-339.

White, F. (1981) The history of the Afromontane archipelago and the scientific need for its conservation. African Journal of Ecology, 19, 33-54.

Wing, S.L., Harrington, G.J., Smith, F.A., Bloch, J.I., Boyer, D.M. \& Freeman, K.H. (2005) Transient Floral Change and Rapid Global Warming at the Paleocene-Eocene Boundary. Science, 310, 993-996.

Winterton, S., Hardy, N. \& Wiegmann, B. (2010) On wings of lace: phylogeny and Bayesian divergence time estimates of Neuropterida (Insecta) based on morphological and molecular data. Systematic Entomology, 35, 349-378.

Withycombe, C.L. (1925) Some Aspects of the Biology and Morphology of the Neuroptera. With special reference to the immature stages and their possible phylogenetic significance. Transactions of the Royal entomological Society of London, 72, 303-411.

Yu, Y., Harris, A.J., Blair, C. \& He, X. (2015) RASP (Reconstruct Ancestral State in Phylogenies): A tool for historical biogeography. Molecular Phylogenetics and Evolution, 87, 46-49. 
Yu, Y., Harris, A.J. \& He, X. (2010) S-DIVA (Statistical Dispersal-Vicariance Analysis): A tool for inferring biogeographic histories. Molecular Phylogenetics and Evolution, 56, 848-850.

Zhu, B., Kidd, W.S.F., Rowley, D.B., Currie, B.S. \& Shafique, N. (2005) Age of Initiation of the India-Asia Collision in the East-Central Himalaya. Journal of Geology, 113, 265-285. 


\section{Supplementary information}
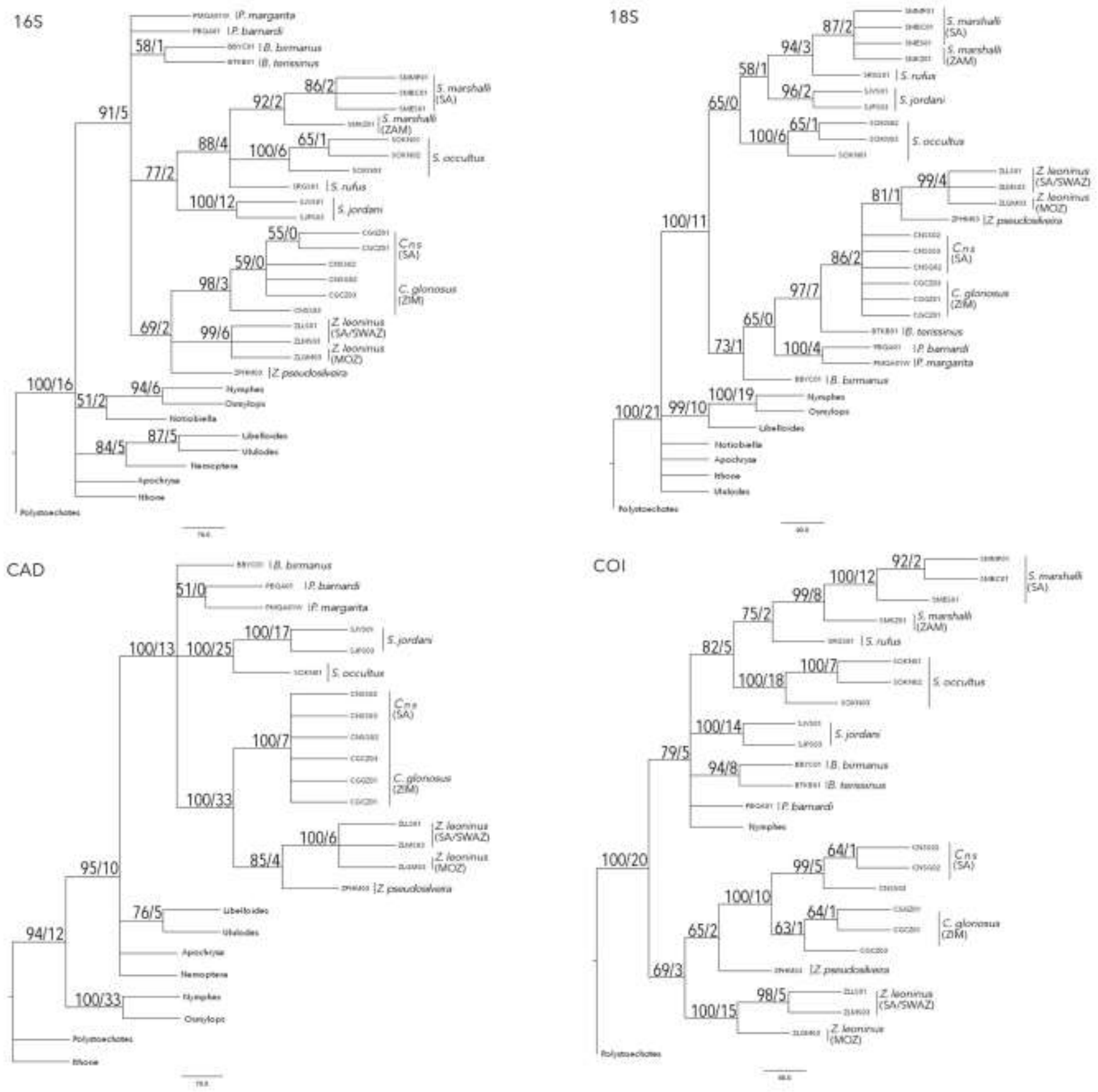

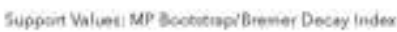

FIGURE S1. 50\% bootstrap strict consensus trees recovered from parsimony analyses of individual gene datasets. 


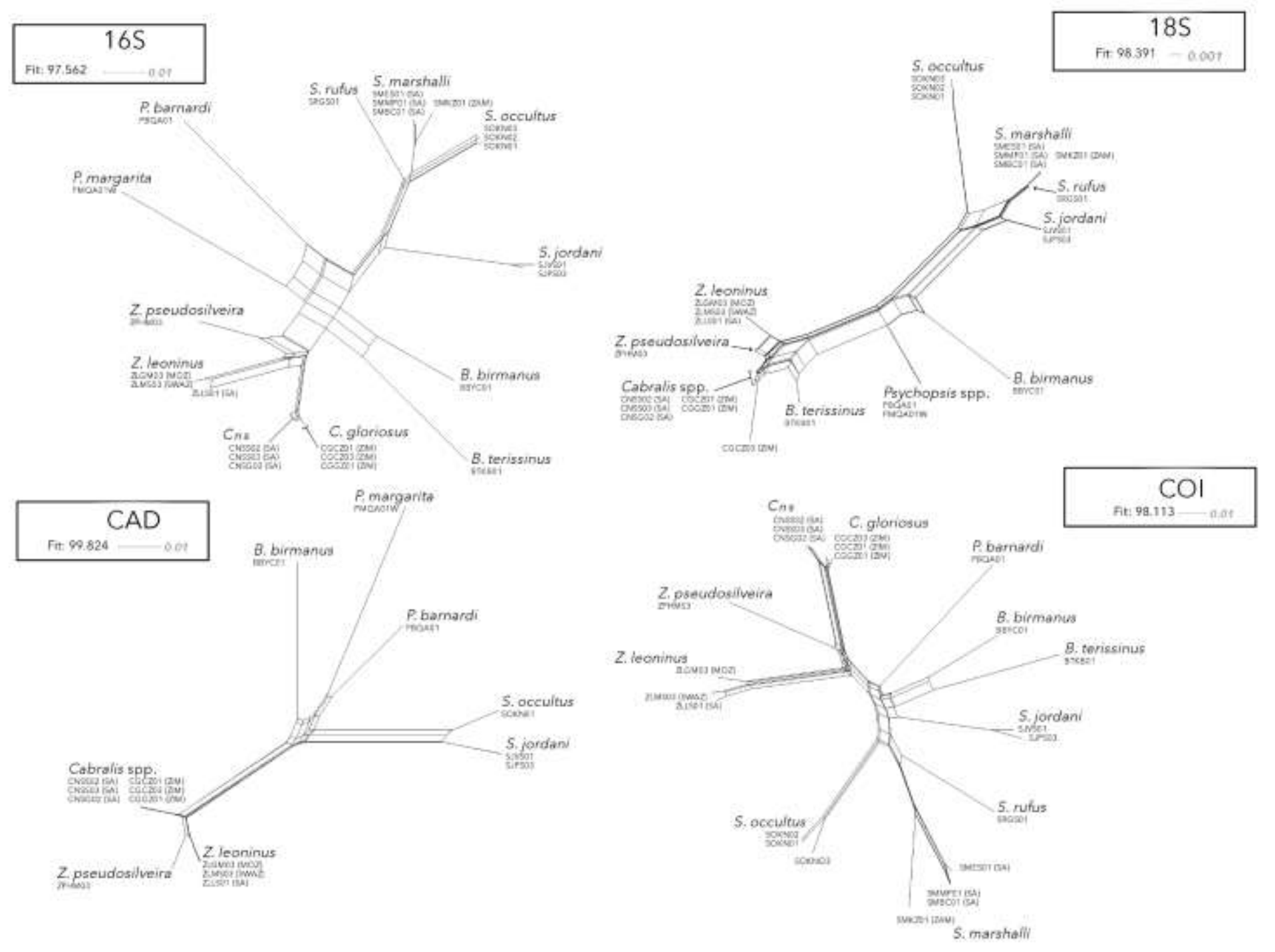

FIGURE S2. Neighbour-net splits trees recovered from SplitsTree analysis of individual gene datasets. Outgroups are excluded. 


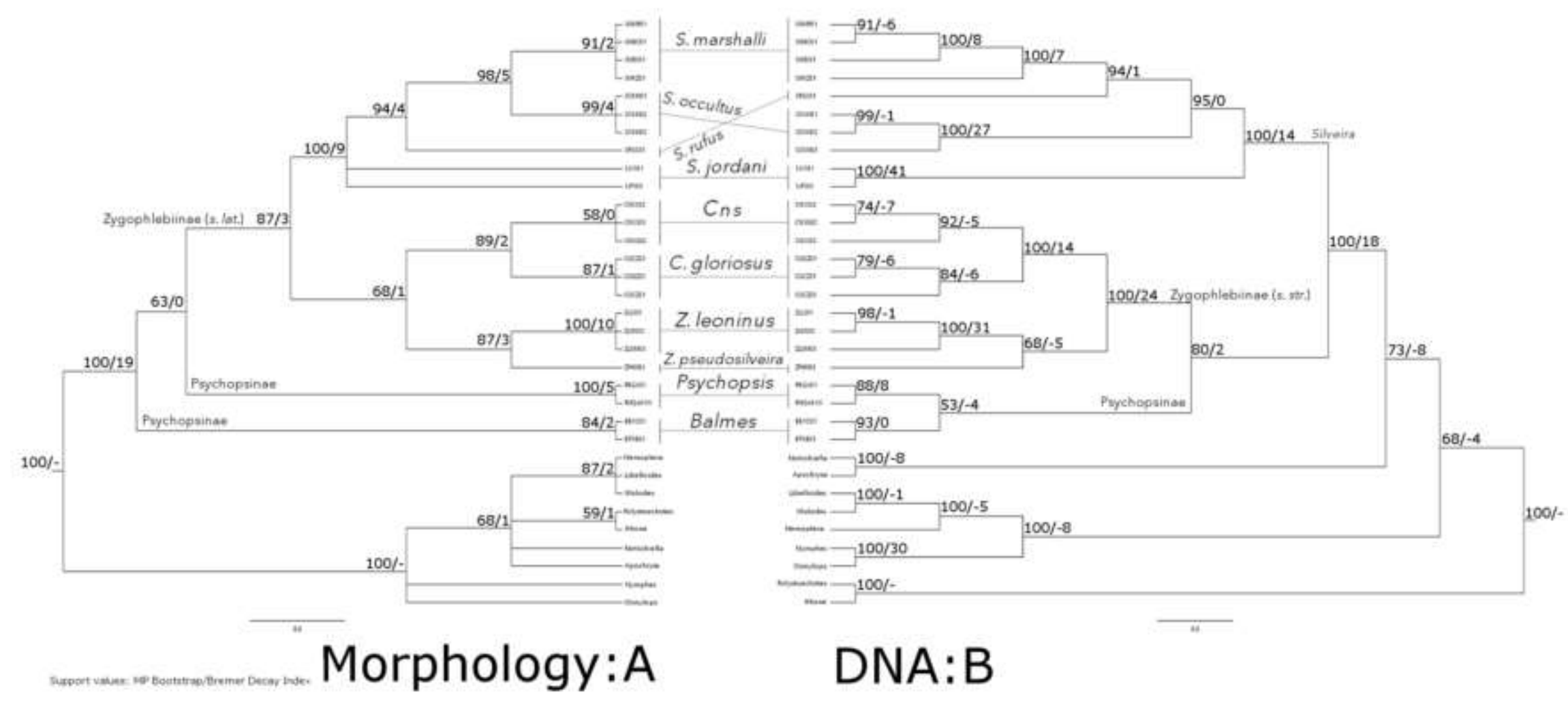

FIGURE S3. Strict consensus trees (bootstrap $=50 \%$ ) recovered from parsimony analyses of $(A)$ the morphological dataset and $(B)$ the concatenated molecular dataset. 
Table S1. Specimen, Database and GenBank accession numbers for specimens used in this study. Database accessions refer mainly to records contained in the Palpares Relational Database (Mansell \& Kenyon, 2002).

\begin{tabular}{|c|c|c|c|c|c|c|c|}
\hline \multirow[b]{2}{*}{ Species } & \multirow[b]{2}{*}{ Sample ID } & \multirow[b]{2}{*}{ Locality } & \multirow[b]{2}{*}{$\begin{array}{l}\text { Palpares Relational } \\
\text { Database Accession }\end{array}$} & \multicolumn{4}{|c|}{ GenBank Accessions } \\
\hline & & & & $16 S$ & $18 \mathrm{~S}$ & $\mathrm{COI}$ & CAD \\
\hline Silveira jordani & $\begin{array}{l}\text { SJVS01 } \\
\text { SJPS03 }\end{array}$ & $\begin{array}{l}\text { Verlatenkloof, SA } \\
\text { Prince Albert, SA }\end{array}$ & $\begin{array}{l}\text { NEUR52639 } \\
\text { NEUR52645 }\end{array}$ & $\begin{array}{l}\text { KT625698 } \\
\text { KT625699 }\end{array}$ & $\begin{array}{l}\text { KT625721 } \\
\text { KT625722 }\end{array}$ & $\begin{array}{l}\text { KT625759 } \\
\text { KT625760 }\end{array}$ & $\begin{array}{l}\text { KT625744 } \\
\text { KT625745 }\end{array}$ \\
\hline Silveira occultus & $\begin{array}{l}\text { SOKN01 } \\
\text { SOKN02 } \\
\text { SOKN03 }\end{array}$ & $\begin{array}{l}\text { Khorixas, NAM } \\
\text { Khorixas, NAM } \\
\text { Khorixas, NAM }\end{array}$ & $\begin{array}{l}\text { NEUR52666 } \\
\text { NEUR52667 } \\
\text { NEUR52668 }\end{array}$ & $\begin{array}{l}\text { KT625700 } \\
\text { KT625701 } \\
\text { KT625702 }\end{array}$ & $\begin{array}{l}\text { KT625723 } \\
\text { KT625724 } \\
\text { KT625725 }\end{array}$ & $\begin{array}{l}\text { KT625761 } \\
\text { KT625762 } \\
\text { KT625763 }\end{array}$ & $\begin{array}{c}\text { KT625746 } \\
-- \\
--\end{array}$ \\
\hline Silveira rufus & SRGS01 & Soutpansberg, SA & NEUR52637 & KT625703 & KT625726 & KT625764 & -- \\
\hline Silveira marshalli & $\begin{array}{l}\text { SMMP01 } \\
\text { SMBC01 } \\
\text { SMKZ01 } \\
\text { SMES01 }\end{array}$ & $\begin{array}{c}\text { Marloth Park, SA } \\
\text { Blyde River Canyon, SA } \\
\text { Kumasamba, ZAM } \\
\text { Ellisras, SA }\end{array}$ & $\begin{array}{l}\text { NEUR52503 } \\
\text { NEUR52504 } \\
\text { WINT00001 } \\
\text { NEUR52512 }\end{array}$ & $\begin{array}{l}\text { KT625704 } \\
\text { KT625705 } \\
\text { KT625706 } \\
\text { KT625707 }\end{array}$ & $\begin{array}{l}\text { KT625727 } \\
\text { KT625728 } \\
\text { KT625729 } \\
\text { KT625730 }\end{array}$ & $\begin{array}{l}\text { KT625765 } \\
\text { KT625766 } \\
\text { KT625767 } \\
\text { KT625768 }\end{array}$ & $\begin{array}{l}-- \\
-- \\
-- \\
--\end{array}$ \\
\hline Zygophlebius leoninus & $\begin{array}{l}\text { ZLLS01 } \\
\text { ZLMS03 } \\
\text { ZLGM03 }\end{array}$ & $\begin{array}{c}\text { Lekgalameetse res., SA } \\
\text { Mlawula res., SWAZ } \\
\text { Gorongosa, MOZ }\end{array}$ & $\begin{array}{l}\text { NEUR52647 } \\
\text { NEUR52649 } \\
\text { NEUR52658 }\end{array}$ & $\begin{array}{l}\text { KT625708 } \\
\text { KT625709 } \\
\text { KT625710 }\end{array}$ & $\begin{array}{l}\text { KT625731 } \\
\text { KT625732 } \\
\text { KT625733 }\end{array}$ & $\begin{array}{l}\text { KT625769 } \\
\text { KT625770 } \\
\text { KT625771 }\end{array}$ & $\begin{array}{l}\text { KT625747 } \\
\text { KT625748 } \\
\text { KT625749 }\end{array}$ \\
\hline $\begin{array}{l}\text { Zygophlebius } \\
\text { pseudosilveira }\end{array}$ & ZPHM03 & Hoogenoeg, SA & NEUR52509 & KT625711 & KT625734 & KT625772 & KT625750 \\
\hline Cabralis gloriosus & $\begin{array}{l}\text { CGCZ01 } \\
\text { CGCZ03 } \\
\text { CGGZ01 }\end{array}$ & $\begin{array}{l}\text { Chirinda Forest, ZIM } \\
\text { Chirinda Forest, ZIM } \\
\text { Gurunguhwe Mt., ZIM }\end{array}$ & $\begin{array}{l}\text { NEUR52651 } \\
\text { NEUR52653 } \\
\text { NEUR52655 }\end{array}$ & $\begin{array}{l}\text { KT625712 } \\
\text { KT625713 } \\
\text { KT625714 }\end{array}$ & $\begin{array}{l}\text { KT625735 } \\
\text { KT625736 } \\
\text { KT625737 }\end{array}$ & $\begin{array}{l}\text { KT625773 } \\
\text { KT625774 } \\
\text { KT625775 }\end{array}$ & $\begin{array}{l}\text { KT625751 } \\
\text { KT625752 } \\
\text { KT625753 }\end{array}$ \\
\hline Cns & $\begin{array}{l}\text { CNSS02 } \\
\text { CNSS03 } \\
\text { CNSG02 }\end{array}$ & $\begin{array}{l}\text { Soutpansberg, SA } \\
\text { Soutpansberg, SA } \\
\text { Soutpansberg, SA }\end{array}$ & $\begin{array}{l}\text { NEUR52501 } \\
\text { NEUR52507 } \\
\text { NEUR52636 }\end{array}$ & $\begin{array}{l}\text { KT625715 } \\
\text { KT625716 } \\
\text { KT625717 }\end{array}$ & $\begin{array}{l}\text { KT625738 } \\
\text { KT625739 } \\
\text { KT625740 }\end{array}$ & $\begin{array}{l}\text { KT625776 } \\
\text { KT625777 } \\
\text { KT625778 }\end{array}$ & $\begin{array}{l}\text { KT625754 } \\
\text { KT625755 } \\
\text { KT625756 }\end{array}$ \\
\hline Psychopsis margarita & PMQA01W & Queensland, AUS & WINT00002 & EU734897 & EU815280 & -- & EU860149 \\
\hline Psychopsis barnardi & PBQA01 & Queensland, AUS & WINT00003 & KT625718 & KT625741 & KT625779 & KT625757 \\
\hline Balmes terrissinus & BTKB01 & Kuankuoshui res., CHI & LIUC00001 & KT625719 & KT625742 & KT625780 & -- \\
\hline Balmes birmanus & BBYC01 & Kunming, $\mathrm{CHI}$ & WINT00004 & KT625720 & KT625743 & KT625781 & KT625758 \\
\hline $\begin{array}{l}\text { Polystoechotes } \\
\text { punctatus }\end{array}$ & Polystoechotes & Idaho, USA & CASENT8092171* & EU734893 & EU815277 & FJ1713251 & EU860146 \\
\hline Notiobiella viridis & Notiobiella & Queensland, AUS & CASENT8092205* & EU734883 & EU815266 & -- & -- \\
\hline Ithone fulva & Ithone & Queensland, AUS & CASENT8092184* & EU734865 & EU815247 & -- & EU860118 \\
\hline Apochrysa lutea & Apochrysa & Queensland, AUS & CASC203* & DQ399285² & EU815269 & -- & EU860139 \\
\hline $\begin{array}{l}\text { Nymphes } \\
\text { myrmeleonides }\end{array}$ & Nymphes & Queensland, AUS & CASENT8092181* & EU734884 & EU815268 & $\mathrm{KJ} 461322^{3}$ & EU860137 \\
\hline $\begin{array}{l}\text { Libelloides } \\
\text { rhomboideus }\end{array}$ & Libelloides & Peloponnisos, GREECE & CASENT8092187* & EU734868 & EU815250 & -- & EU860121 \\
\hline Nemoptera coa & Nemoptera & Peloponnisos, GREECE & CASENT8092191* & EU734878 & -- & -- & EU860131 \\
\hline Osmylops armatus & Osmylops & Queensland, AUS & CASENT8092182* & EU734886 & EU815270 & -- & EU860140 \\
\hline $\begin{array}{c}\text { Ululodes } \\
\text { quadripunctatus }\end{array}$ & Ululodes & North Carolina, USA & CASENT8092188* & EU734854 & EU815235 & -- & EU860109 \\
\hline
\end{tabular}

*Specimens not contained in Palpares Relational database. ${ }^{1,2,3}$ Sequences obtained from different studies for that taxon. ${ }^{1}$ with different locality data ${ }^{1}$ British Columbia, Canada. 
Table S2: Matrix of morphological characters and states used in the study

\begin{tabular}{|c|c|c|c|c|c|c|c|c|}
\hline \multirow{5}{*}{$\begin{array}{l}\text { Taxon character states coded with a } \\
\text { dash (-) belong to a state that is } \\
\text { irrelevant for that character system } \\
\text { and are thus excluded from analysis of } \\
\text { that character. }\end{array}$} & \multicolumn{3}{|l|}{ Head } & \multicolumn{5}{|l|}{ Thorax } \\
\hline & $\begin{array}{c}\text { Vertex, } \\
\text { ocellar/cranial } \\
\text { pulvinae }\end{array}$ & $\begin{array}{c}\text { Margin of } \\
\text { torulus/medial } \\
\text { antennifer }\end{array}$ & Head Colour & $\begin{array}{c}\text { Forewing, } \\
\text { transverse } \\
\text { bilineate } \\
\text { fasciae }\end{array}$ & $\begin{array}{l}\text { Forewing } \\
\text { Markings, } \\
\text { colour }\end{array}$ & $\begin{array}{l}\text { Forewing } \\
\text { Markings, } \\
\text { patterning }\end{array}$ & $\begin{array}{l}\text { Forewing, no. } \\
\text { of Sc-R1 } \\
\text { crossveins }\end{array}$ & $\begin{array}{l}\text { Forewing, } \\
\text { crossveins of } \\
\text { costal gradate } \\
\text { series }\end{array}$ \\
\hline & $\begin{array}{l}0-3 \text { pulvinae } \\
1-2 \text { pulvinae } \\
2-0 \text { pulvinae }\end{array}$ & $\begin{array}{l}0 \text { - absent } \\
1 \text { - present }\end{array}$ & $\begin{array}{l}0 \text { - light yellow } \\
1 \text { - darker yellow } \\
2 \text { - reddish brown } \\
3 \text { - dark brown } \\
4 \text { - pale testaceous } \\
5 \text { - dark brown } \\
\text { testaceous }\end{array}$ & $\begin{array}{l}0 \text { - absent } \\
1 \text { - present }\end{array}$ & $\begin{array}{l}0 \text { - white } \\
1 \text { - yellowish } \\
\text { hyaline } \\
\text { 2- brownish } \\
\text { 3- Pale grey } \\
\text { brown }\end{array}$ & 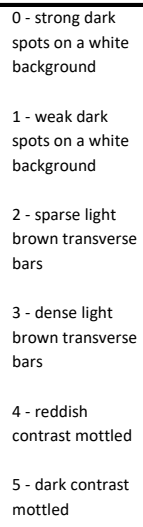 & $\begin{array}{l}0-1 \text { (occasional } \\
\text { adventitious } \\
\text { crossveins) } \\
1->4 \text { (but rarely } \\
<10 \text { ) }\end{array}$ & $\begin{array}{l}0 \text {-absent }(<6) \\
1-\text { numerous }\end{array}$ \\
\hline & 0 & 0 & 0 & 0 & 0 & 0 & 0 & 0 \\
\hline & 1 & 2 & 3 & 4 & 5 & 6 & 7 & 8 \\
\hline \multicolumn{9}{|l|}{ Australian/south east Asian tax } \\
\hline Psychopsis barnardi & 1 & 0 & 4 & 1 & 1 & - & 1 & 1 \\
\hline Psychopsis margarita & 1 & 0 & 4 & 0 & 1 & - & 1 & 1 \\
\hline Balmes birmanus & 1 & 0 & 5 & 0 & 3 & - & 1 & 0 \\
\hline Balmes terissinus & 1 & 0 & 5 & 0 & 3 & - & 1 & 0 \\
\hline \multicolumn{9}{|l|}{ Afrotropical taxa } \\
\hline Cabralis gloriosus & 1 & 1 & 1 & 0 & 0 & 0 & 1 & 1 \\
\hline Cabralis puritus & 1 & 1 & 0 & 0 & 0 & 1 & 1 & 1 \\
\hline Zygophlebius leoninus & 1 & 1 & 0 & 0 & 1 & 2 & 1 & 1 \\
\hline Zygophlebius zebra & 1 & 1 & 0 & 0 & 1 & 2 & 1 & 1 \\
\hline Zygophlebius pseudosilveira & 1 & 1 & 2 & 0 & 3 & 3 & 1 & 0 \\
\hline Silveira jordani & 0 & 1 & 2 & 0 & 2 & 4 & 1 & 1 \\
\hline Silveira rufus & 0 & 1 & 2 & 0 & 2 & 4 & 1 & 1 \\
\hline Silveira occultus & 0 & 1 & 3 & 0 & 2 & 5 & 1 & 1 \\
\hline Silveira marshalli & 0 & 1 & 3 & 0 & 2 & 5 & 1 & 1 \\
\hline \multicolumn{9}{|l|}{ Outgroup taxa } \\
\hline Polystoechotes punctatus & 2 & 0 & - & - & - & - & 0 & 0 \\
\hline Notiobiella viridis & 2 & 0 & - & - & - & - & 0 & 0 \\
\hline Apochrysa lutea & 2 & 0 & - & - & - & - & 0 & 0 \\
\hline Ithone fulva & 2 & 0 & - & - & - & - & 0 & 0 \\
\hline Nymphes myrmeleonides & - & 0 & - & - & - & - & 1 & 0 \\
\hline Libelloides rhomboideus & 2 & 0 & - & - & - & - & 0 & 0 \\
\hline Nemoptera coa & 2 & 0 & - & - & - & - & 0 & 0 \\
\hline Osmylops armatus & 2 & 0 & - & - & - & - & 1 & 0 \\
\hline Ululodes quadripunctatus & 2 & 0 & - & - & - & - & 0 & 0 \\
\hline
\end{tabular}


Table S2: Matrix of morphological characters and states used in the study

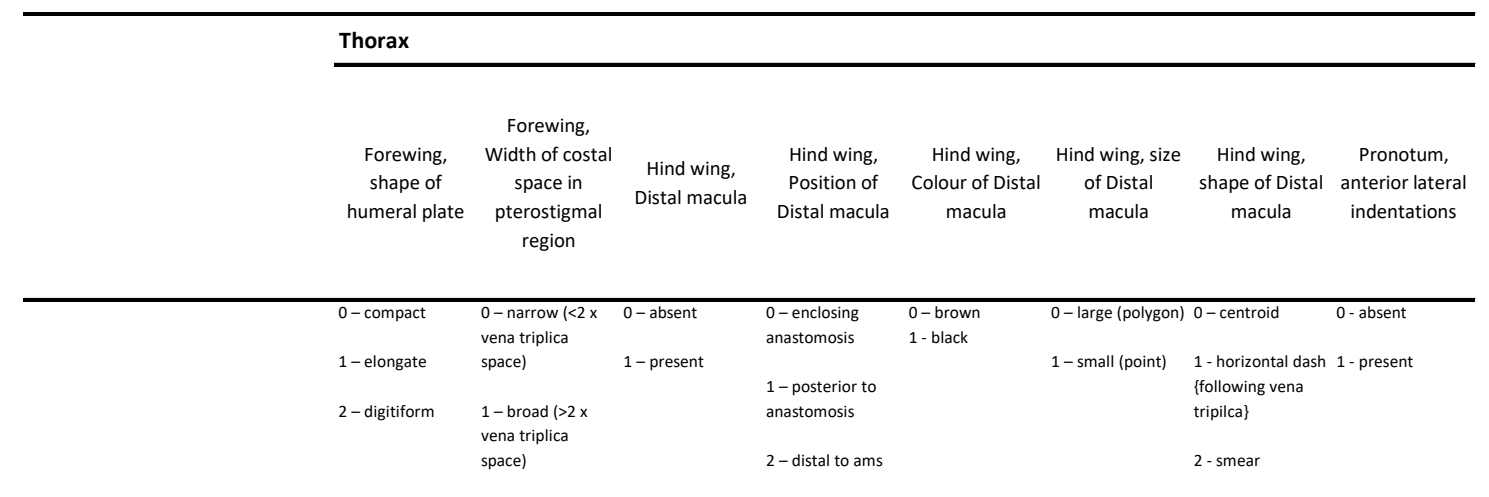

\begin{tabular}{|c|c|c|c|c|c|c|c|c|}
\hline & $\begin{array}{l}0 \\
9\end{array}$ & $\begin{array}{l}1 \\
0\end{array}$ & $\begin{array}{l}1 \\
1\end{array}$ & $\begin{array}{l}1 \\
2\end{array}$ & $\begin{array}{l}1 \\
3\end{array}$ & $\begin{array}{l}1 \\
4\end{array}$ & $\begin{array}{l}1 \\
5\end{array}$ & $\begin{array}{l}1 \\
6\end{array}$ \\
\hline \multicolumn{9}{|l|}{ Australian/south east Asian taxa } \\
\hline Psychopsis barnardi & 2 & 1 & 1 & 1 & 0 & 0 & 2 & 1 \\
\hline Psychopsis margarita & 2 & 1 & 1 & 1 & 0 & 0 & 2 & 1 \\
\hline Balmes birmanus & 0 & 1 & 0 & - & - & - & - & 1 \\
\hline Balmes terissinus & 0 & 1 & 0 & - & - & - & - & 1 \\
\hline \multicolumn{9}{|l|}{ Afrotropical taxa } \\
\hline Cabralis gloriosus & 1 & 1 & 1 & 0 & 0 & 1 & 2 & 1 \\
\hline Cabralis puritus & 1 & 1 & 0 & - & - & - & - & 1 \\
\hline Zygophlebius leoninus & 2 & 1 & 1 & 0 & 1 & 1 & 0 & 1 \\
\hline Zygophlebius zebra & 2 & 1 & 1 & 0 & 1 & 1 & 0 & 1 \\
\hline Zygophlebius pseudosilveira & 1 & 1 & 1 & 0 & 1 & 1 & 0 & 1 \\
\hline Silveira jordani & 1 & 1 & 0 & - & - & - & - & 1 \\
\hline Silveira rufus & 1 & 1 & 0 & - & - & - & - & 1 \\
\hline Silveira occultus & 1 & 1 & 0 & - & - & - & - & 1 \\
\hline Silveira marshalli & 1 & 1 & 0 & - & - & - & - & 1 \\
\hline \multicolumn{9}{|l|}{ Outgroup taxa } \\
\hline Polystoechotes punctatus & 0 & 0 & 0 & - & - & - & - & 0 \\
\hline Notiobiella viridis & 0 & 0 & 0 & - & - & - & - & 0 \\
\hline Apochrysa lutea & 0 & 0 & 0 & - & - & - & - & 0 \\
\hline Ithone fulva & 0 & 0 & 0 & - & - & - & - & 0 \\
\hline Nymphes myrmeleonides & 0 & 0 & 0 & - & - & - & - & 0 \\
\hline Libelloides rhomboideus & 0 & 0 & 0 & - & - & - & - & 0 \\
\hline Nemoptera coa & 0 & 0 & 0 & - & - & - & - & 0 \\
\hline Osmylops armatus & 0 & 0 & 0 & - & - & - & - & 0 \\
\hline Ululodes quadripunctatus & 0 & 0 & 0 & - & - & - & - & 0 \\
\hline
\end{tabular}


Table S2: Matrix of morphological characters and states used in the study

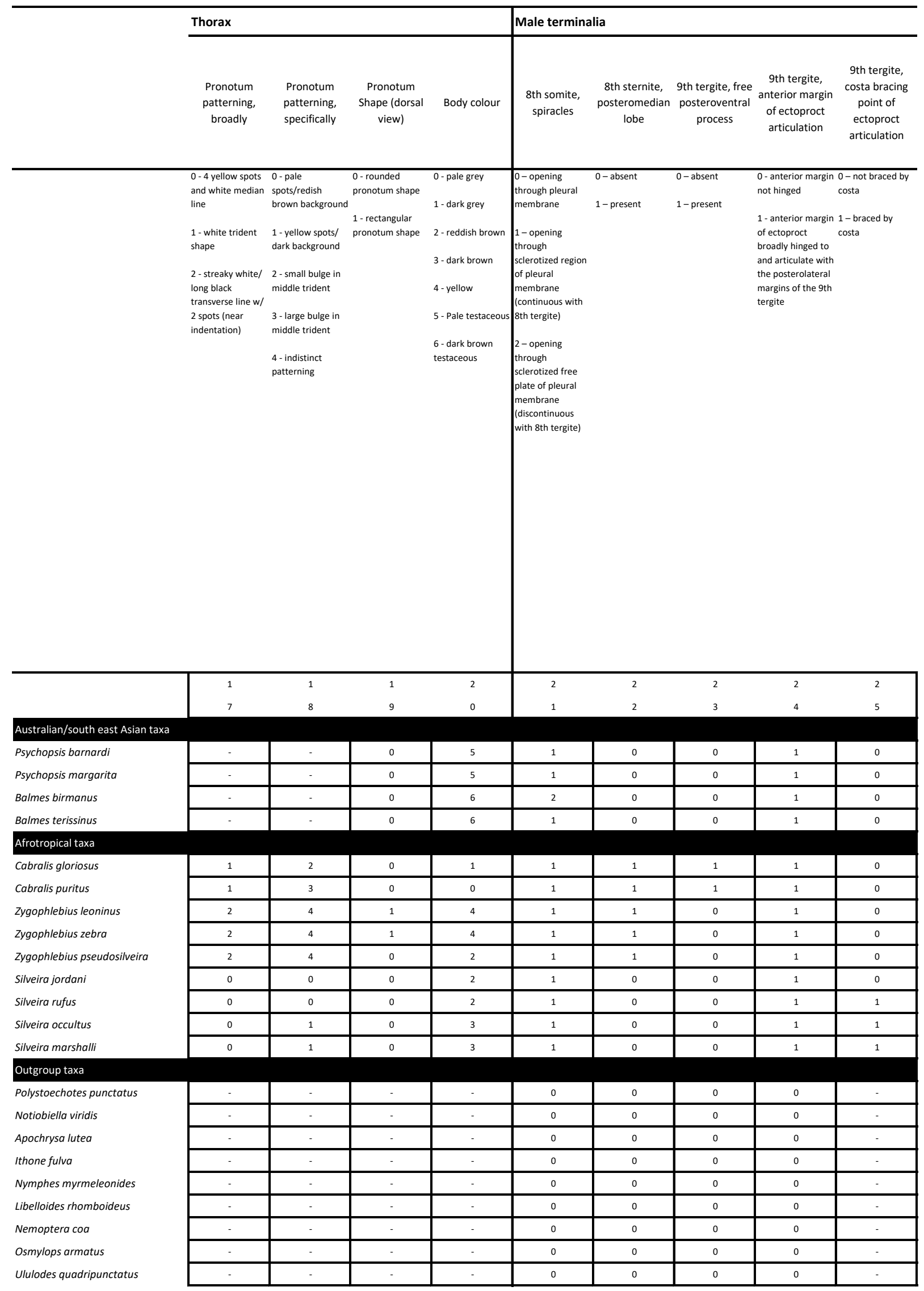


Table S2: Matrix of morphological characters and states used in the study

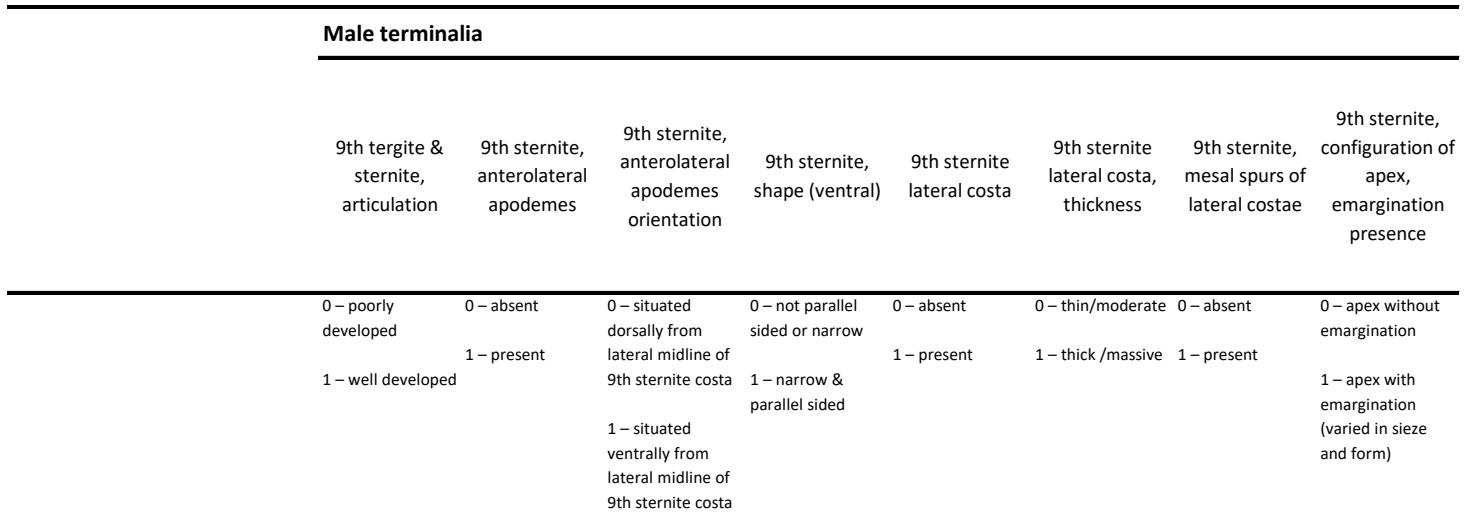

\begin{tabular}{|c|c|c|c|c|c|c|c|c|}
\hline & $\begin{array}{l}2 \\
6\end{array}$ & $\begin{array}{l}2 \\
7\end{array}$ & $\begin{array}{l}2 \\
8\end{array}$ & $\begin{array}{l}2 \\
9\end{array}$ & $\begin{array}{l}3 \\
0\end{array}$ & $\begin{array}{l}3 \\
1\end{array}$ & $\begin{array}{l}3 \\
2\end{array}$ & $\begin{array}{l}3 \\
3\end{array}$ \\
\hline \multicolumn{9}{|l|}{ Australian/south east Asian taxa } \\
\hline Psychopsis barnardi & 1 & 1 & 1 & 0 & 1 & 1 & 1 & 1 \\
\hline Psychopsis margarita & 1 & 1 & 1 & 0 & 1 & 1 & 0 & 1 \\
\hline Balmes birmanus & 1 & 1 & 1 & 0 & 1 & 0 & 0 & 0 \\
\hline Balmes terissinus & 1 & 1 & 1 & 0 & 1 & 0 & 0 & 0 \\
\hline \multicolumn{9}{|l|}{ Afrotropical taxa } \\
\hline Cabralis gloriosus & 1 & 1 & 0 & 0 & 1 & 0 & 0 & 0 \\
\hline Cabralis puritus & 1 & 1 & 0 & 0 & 1 & 0 & 0 & 0 \\
\hline Zygophlebius leoninus & 1 & 1 & 0 & 0 & 1 & 0 & 0 & 1 \\
\hline Zygophlebius zebra & 1 & 1 & 0 & 0 & 1 & 0 & 0 & 1 \\
\hline Zygophlebius pseudosilveira & 1 & 1 & 0 & 0 & 1 & 0 & 0 & 0 \\
\hline Silveira jordani & 1 & 1 & 0 & 1 & 1 & 0 & 0 & 1 \\
\hline Silveira rufus & 1 & 1 & 0 & 1 & 1 & 0 & 0 & 1 \\
\hline Silveira occultus & 1 & 1 & 0 & 1 & 0 & 0 & 0 & 1 \\
\hline Silveira marshalli & 1 & 1 & 0 & 1 & 1 & 0 & 0 & 1 \\
\hline \multicolumn{9}{|l|}{ Outgroup taxa } \\
\hline Polystoechotes punctatus & 0 & 0 & - & 0 & 1 & 0 & 0 & - \\
\hline Notiobiella viridis & 0 & 0 & - & 0 & 0 & - & 0 & - \\
\hline Apochrysa lutea & 0 & 0 & - & 0 & 0 & - & 0 & - \\
\hline Ithone fulva & 0 & 0 & - & 0 & 1 & 0 & 0 & - \\
\hline Nymphes myrmeleonides & 0 & 0 & - & 0 & 0 & - & 0 & 0 \\
\hline Libelloides rhomboideus & 0 & 0 & - & 0 & 0 & - & 0 & - \\
\hline Nemoptera coa & 0 & 0 & - & 0 & 0 & - & 0 & - \\
\hline Osmylops armatus & 0 & 0 & - & 0 & 0 & - & 0 & - \\
\hline Ululodes quadripunctatus & 0 & 0 & - & 0 & 0 & - & 0 & - \\
\hline
\end{tabular}


Table S2: Matrix of morphological characters and states used in the study

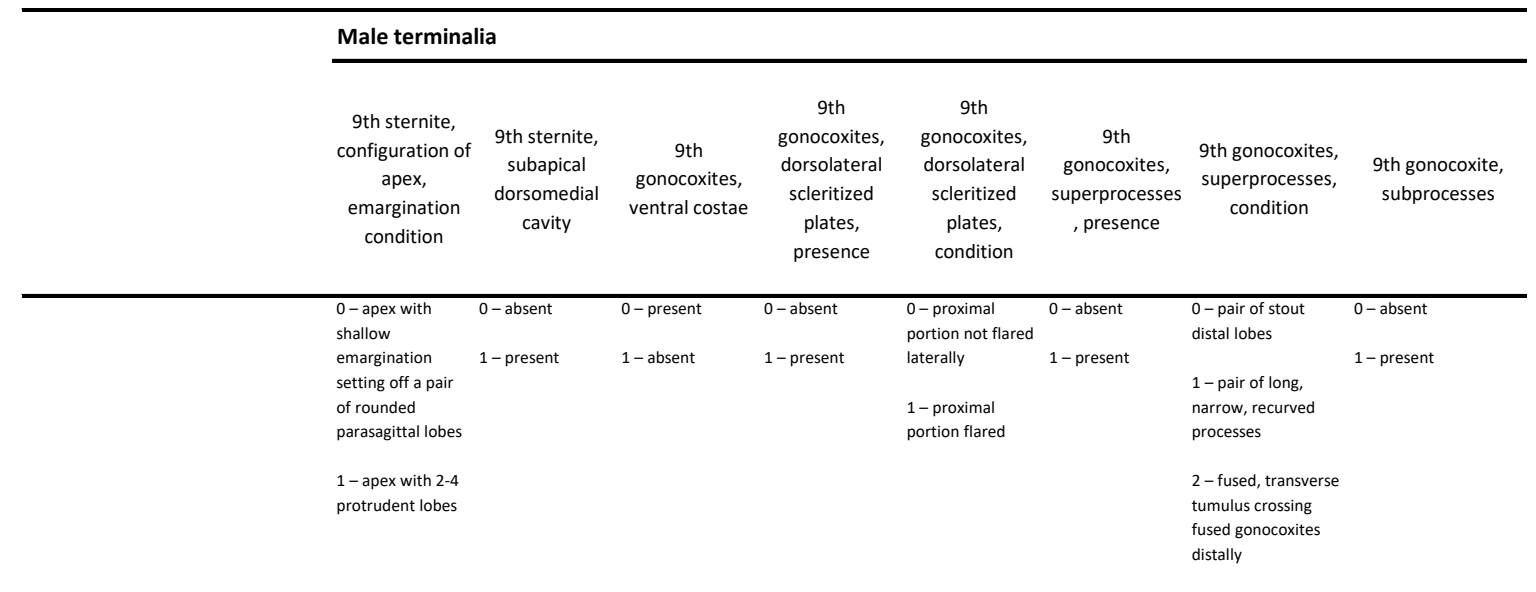

\begin{tabular}{|c|c|c|c|c|c|c|c|c|}
\hline & $\begin{array}{l}3 \\
4\end{array}$ & $\begin{array}{l}3 \\
5\end{array}$ & $\begin{array}{l}3 \\
6\end{array}$ & $\begin{array}{l}3 \\
7\end{array}$ & $\begin{array}{l}3 \\
8\end{array}$ & $\begin{array}{l}3 \\
9\end{array}$ & $\begin{array}{l}4 \\
0\end{array}$ & $\begin{array}{l}4 \\
1\end{array}$ \\
\hline \multicolumn{9}{|c|}{ Australian/south east Asian taxa } \\
\hline Psychopsis margarita & 1 & 0 & 0 & 1 & 1 & 1 & 1 & $\overline{0}$ \\
\hline Balmes birmanus & - & 0 & 1 & 1 & 1 & 1 & 2 & 0 \\
\hline \multicolumn{9}{|l|}{ Afrotropical taxa } \\
\hline Cabralis gloriosus & - & 0 & 0 & 1 & 1 & 0 & - & 0 \\
\hline Cabralis puritus & - & 0 & 0 & 1 & 1 & 0 & - & 0 \\
\hline Zygophlebius leoninus & 0 & 0 & 0 & 1 & 2 & 0 & - & 0 \\
\hline Zygophlebius zebra & 0 & 0 & 0 & 1 & 2 & 0 & - & 0 \\
\hline Silveira occultus & 0 & 0 & 0 & 1 & 1 & 0 & - & 0 \\
\hline Silveira marshalli & 0 & 0 & 0 & 1 & 1 & 0 & - & 0 \\
\hline \multicolumn{9}{|l|}{ Outgroup taxa } \\
\hline Polystoechotes punctatus & - & 0 & 1 & 1 & 1 & 0 & - & 0 \\
\hline Notiobiella viridis & - & 0 & - & 1 & 1 & 0 & - & 0 \\
\hline Apochrysa lutea & - & 0 & - & 1 & 1 & 0 & - & 0 \\
\hline Ithone fulva & - & 0 & 1 & 1 & 1 & 0 & - & 0 \\
\hline Nymphes myrmeleonides & - & 0 & 0 & 1 & 1 & 0 & - & 0 \\
\hline Libelloides rhomboideus & - & 0 & 0 & 1 & 1 & 0 & - & 0 \\
\hline Nemoptera coa & - & 0 & 0 & 1 & 1 & 0 & - & 0 \\
\hline
\end{tabular}


Table S2: Matrix of morphological characters and states used in the study

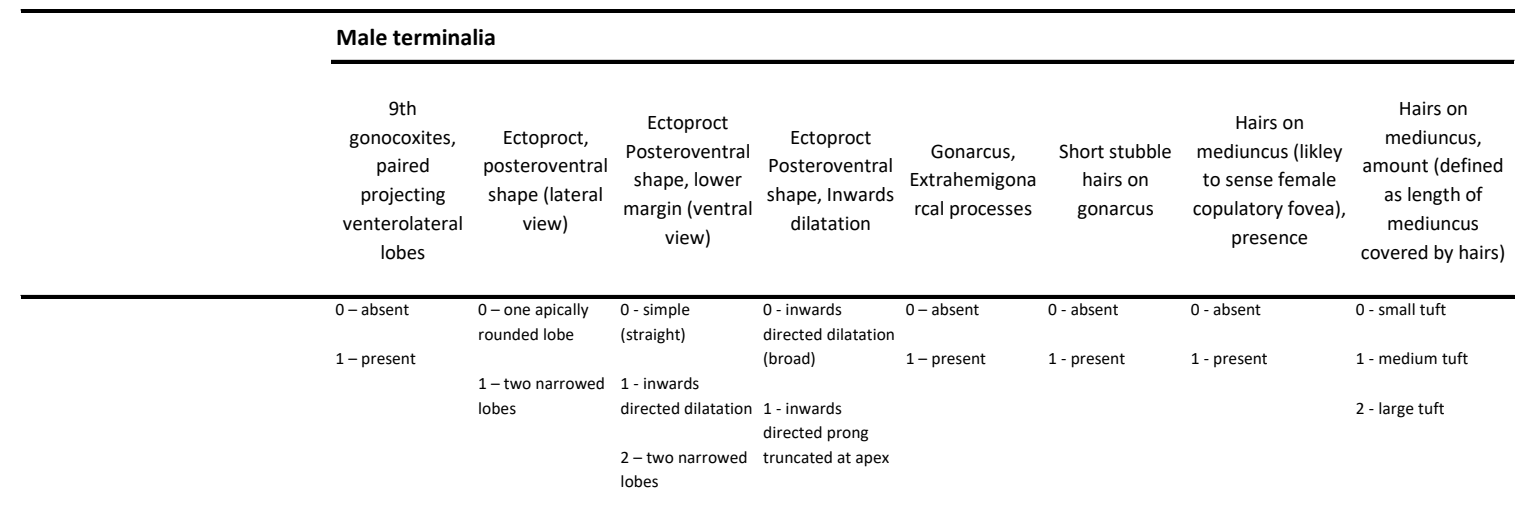

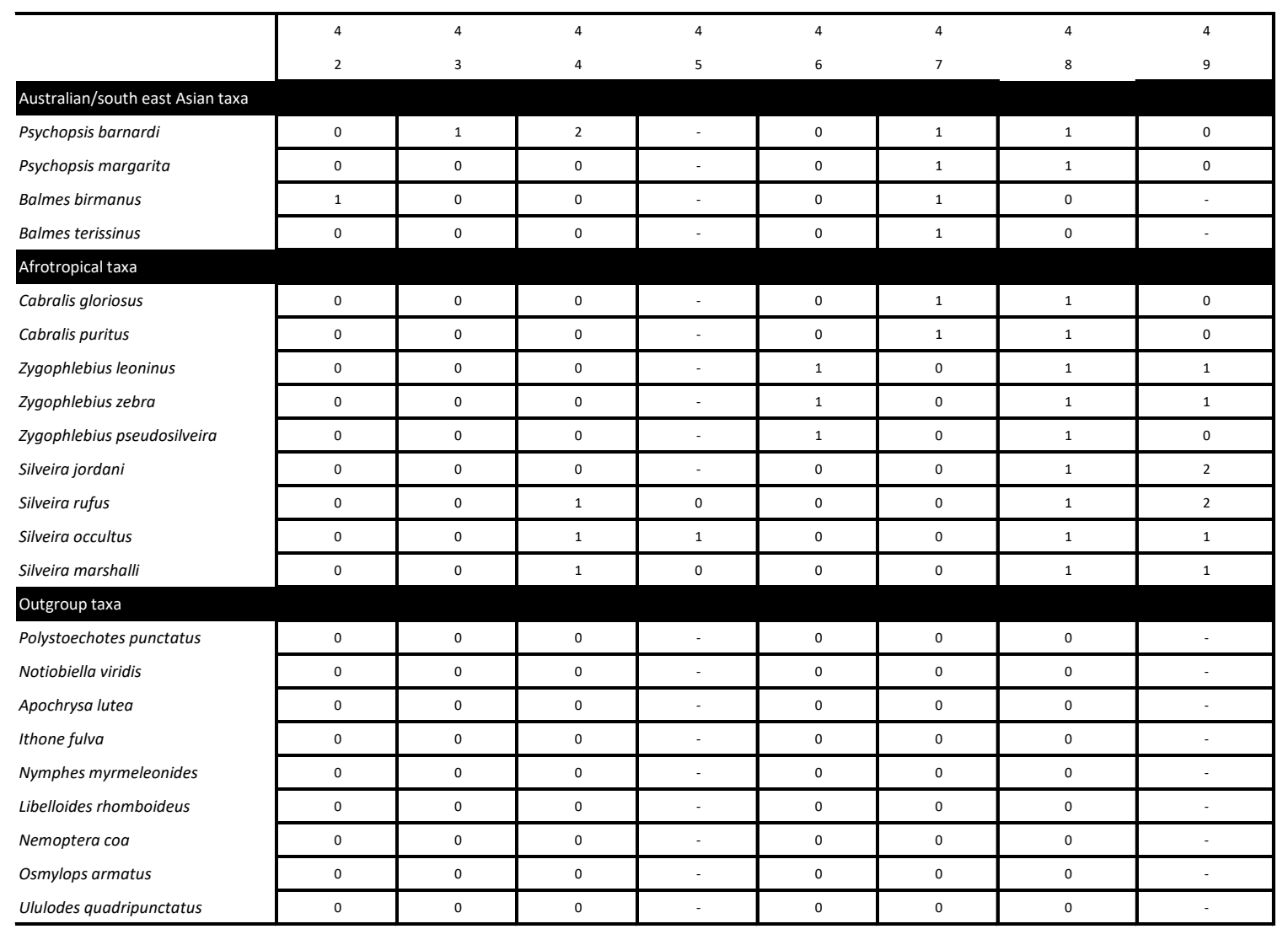


Table S2: Matrix of morphological characters and states used in the study

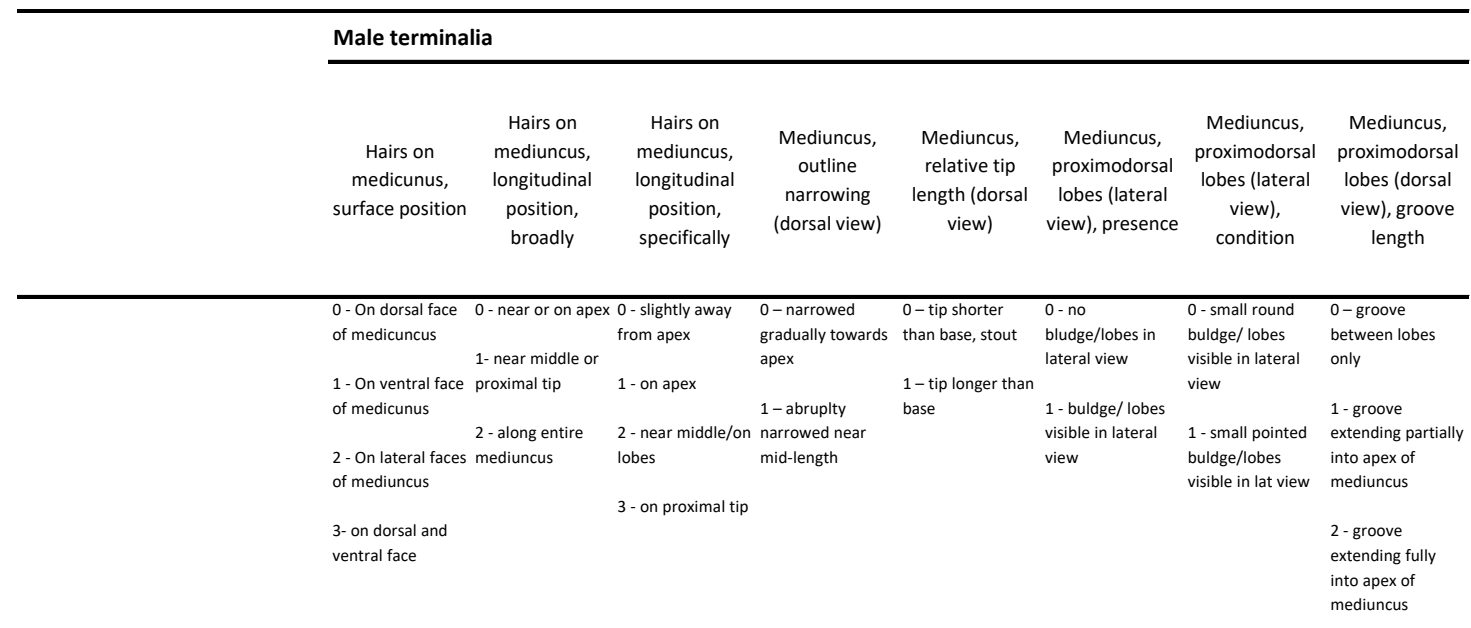

\begin{tabular}{|c|c|c|c|c|c|c|c|c|}
\hline & $\begin{array}{l}5 \\
0\end{array}$ & $\begin{array}{l}5 \\
1\end{array}$ & $\begin{array}{l}5 \\
2\end{array}$ & $\begin{array}{l}5 \\
3\end{array}$ & $\begin{array}{l}5 \\
4\end{array}$ & $\begin{array}{l}5 \\
5\end{array}$ & $\begin{array}{l}5 \\
6\end{array}$ & $\begin{array}{l}5 \\
7\end{array}$ \\
\hline \multicolumn{9}{|l|}{ Australian/south east Asian taxa } \\
\hline Psychopsis barnardi & 3 & 0 & 0 & 0 & - & 0 & - & - \\
\hline Psychopsis margarita & 0 & 0 & 2 & 0 & - & 1 & 0 & 1 \\
\hline Balmes birmanus & - & - & - & 0 & - & 0 & - & - \\
\hline Balmes terissinus & - & - & - & 0 & - & 0 & - & - \\
\hline \multicolumn{9}{|l|}{ Afrotropical taxa } \\
\hline Cabralis gloriosus & 1 & 0 & 1 & 0 & 1 & 0 & - & - \\
\hline Cabralis puritus & 1 & 0 & 1 & 0 & 1 & 0 & - & - \\
\hline Zygophlebius leoninus & 0 & 1 & 2 & 0 & 1 & 1 & 1 & 2 \\
\hline Zygophlebius zebra & 0 & 0 & 0 & 0 & 1 & 1 & 1 & 2 \\
\hline Zygophlebius pseudosilveira & 2 & 0 & 1 & 0 & 1 & 0 & - & - \\
\hline Silveira jordani & 0 & 2 & - & 0 & 0 & 0 & - & - \\
\hline Silveira rufus & 0 & 1 & 2 & 1 & 0 & 1 & 0 & 1 \\
\hline Silveira occultus & 0 & 1 & 2 & 1 & 1 & 1 & 0 & 1 \\
\hline Silveira marshalli & 0 & 1 & 2 & 1 & 1 & 1 & 0 & 0 \\
\hline \multicolumn{9}{|l|}{ Outgroup taxa } \\
\hline Polystoechotes punctatus & - & - & - & 0 & - & 0 & - & - \\
\hline Notiobiella viridis & - & - & - & 0 & - & 0 & - & - \\
\hline Apochrysa lutea & - & - & - & 0 & - & 0 & - & - \\
\hline Ithone fulva & - & - & - & 0 & - & 0 & - & - \\
\hline Nymphes myrmeleonides & - & - & - & 0 & - & 0 & - & - \\
\hline Libelloides rhomboideus & - & - & - & 0 & - & 0 & - & - \\
\hline Nemoptera coa & - & - & - & 0 & - & 0 & - & - \\
\hline Osmylops armatus & - & - & - & 0 & - & 0 & - & - \\
\hline Ululodes quadripunctatus & - & - & - & 0 & - & 0 & - & - \\
\hline
\end{tabular}


Table S2: Matrix of morphological characters and states used in the study

\begin{tabular}{llllll}
\hline & Male terminalia & & & \\
\hline
\end{tabular}

\begin{tabular}{|c|c|c|c|c|c|c|c|c|}
\hline & $\begin{array}{l}5 \\
8\end{array}$ & $\begin{array}{l}5 \\
9\end{array}$ & $\begin{array}{l}6 \\
0\end{array}$ & $\begin{array}{l}6 \\
1\end{array}$ & $\begin{array}{l}6 \\
2\end{array}$ & $\begin{array}{l}6 \\
3\end{array}$ & $\begin{array}{l}6 \\
4\end{array}$ & $\begin{array}{l}6 \\
5\end{array}$ \\
\hline \multicolumn{9}{|c|}{ Australian/south east Asian taxa } \\
\hline Psychopsis barnardi & 0 & - & - & - & 1 & 1 & 1 & 1 \\
\hline Psychopsis margarita & 1 & - & - & 2 & 2 & 1 & 1 & 1 \\
\hline Balmes birmanus & 0 & - & - & - & 0 & 1 & 1 & 1 \\
\hline Balmes terissinus & 0 & - & - & - & 1 & 1 & 1 & 1 \\
\hline \multicolumn{9}{|l|}{ Afrotropical taxa } \\
\hline Cabralis gloriosus & 0 & 1 & 0 & - & 1 & 1 & 0 & 1 \\
\hline Cabralis puritus & 0 & 1 & 1 & - & 1 & 1 & 0 & 1 \\
\hline Zygophlebius leoninus & 1 & - & - & 1 & 2 & 1 & 0 & 1 \\
\hline Zygophlebius zebra & 1 & - & - & 0 & 2 & 1 & 0 & 1 \\
\hline Zygophlebius pseudosilveira & 0 & - & - & 2 & 2 & 1 & 0 & 1 \\
\hline Silveira jordani & 0 & 0 & - & - & 1 & 1 & 0 & 1 \\
\hline Silveira rufus & 0 & 0 & - & - & 1 & 1 & 0 & 1 \\
\hline Silveira occultus & 0 & 0 & - & - & 1 & 1 & 0 & 1 \\
\hline Silveira marshalli & 1 & 0 & - & - & 1 & 1 & 0 & 1 \\
\hline \multicolumn{9}{|l|}{ Outgroup taxa } \\
\hline Polystoechotes punctatus & 0 & 0 & - & - & 0 & 0 & - & 0 \\
\hline Notiobiella viridis & 0 & 0 & - & - & 0 & 0 & - & 0 \\
\hline Apochrysa lutea & 0 & 0 & - & - & 0 & 0 & - & 0 \\
\hline Ithone fulva & 0 & 0 & - & - & 0 & 0 & - & 0 \\
\hline Nymphes myrmeleonides & 0 & 0 & 1 & - & 0 & 0 & - & 0 \\
\hline Libelloides rhomboideus & 1 & - & - & 2 & 0 & 0 & - & 0 \\
\hline Nemoptera coa & 1 & - & - & 2 & 0 & 0 & - & 0 \\
\hline Osmylops armatus & 0 & - & - & - & 0 & 0 & - & 0 \\
\hline Ululodes quadripunctatus & 1 & - & - & 2 & 0 & 0 & - & 0 \\
\hline
\end{tabular}


Table S2: Matrix of morphological characters and states used in the study

\begin{tabular}{|c|c|c|c|c|c|c|c|c|}
\hline & \multicolumn{5}{|c|}{ Male terminalia } & \multicolumn{3}{|l|}{ Female terminalia } \\
\hline & $\begin{array}{c}\text { Gonosacaccal } \\
\text { membrane, } \\
\text { rounded } \\
\text { spiculate lobes }\end{array}$ & $\begin{array}{l}\text { 7th sternite, } \\
\text { posterior } \\
\text { margin }\end{array}$ & $\begin{array}{c}\text { Copulatory } \\
\text { fovea, shape }\end{array}$ & $\begin{array}{l}\text { Copulatory } \\
\text { fovea, Cusp of } \\
\text { Carina (ridge) }\end{array}$ & $\begin{array}{c}\text { Copulatory } \\
\text { fovea, Cusp of } \\
\text { Carina (ridge), } \\
\text { condition }\end{array}$ & $\begin{array}{l}\text { Copulatory fovea, } \\
\text { Cusp of Carina } \\
\text { (ridge), shape }\end{array}$ & $\begin{array}{l}\text { Copulatory fovea, } \\
\text { Projection on } \\
\text { sigattal Carina }\end{array}$ & $\begin{array}{l}\text { Copulatory fovea, } \\
\text { Projection on } \\
\text { sigattal Carina, } \\
\text { development }\end{array}$ \\
\hline & $\begin{array}{l}0 \text {-absent } \\
1 \text { - present }\end{array}$ & $\begin{array}{l}\begin{array}{l}0-\text { transverse \& } \\
\text { simple (copulatory } \\
\text { fovea absent) }\end{array} \\
1 \text { - With a medial } \\
\text { emargination } \\
\text { (copulatory fovea } \\
\text { present) }\end{array}$ & $\begin{array}{l}0 \text { - spheroid } \\
1 \text { - posteriorly } \\
\text { directed cavity } \\
\text { placed internally } \\
\text { in lateral view, } \\
\text { formed with 8th } \\
\text { sternite } \\
\text { 2- Furrow-like } \\
\text { groove } \\
\text { 3- Pit divided by } \\
\text { ridge }\end{array}$ & $\begin{array}{l}0 \text { - absent } \\
1 \text {-present }\end{array}$ & $\begin{array}{l}0 \text { - thick } \\
1 \text { - projecting } \\
2 \text { - incipient }\end{array}$ & $\begin{array}{l}0 \text { - straight, tapering } \\
1 \text { - bifurcating }\end{array}$ & $\begin{array}{l}\text { - absent } \\
1 \text { - present }\end{array}$ & $\begin{array}{l}0 \text { - short } \\
1 \text { - long } \\
2 \text { - incipient }\end{array}$ \\
\hline & $\begin{array}{l}6 \\
6\end{array}$ & $\begin{array}{l}6 \\
7\end{array}$ & $\begin{array}{l}6 \\
8\end{array}$ & $\begin{array}{l}6 \\
9\end{array}$ & $\begin{array}{l}7 \\
0\end{array}$ & $\begin{array}{l}7 \\
1\end{array}$ & $\begin{array}{l}7 \\
2\end{array}$ & $\begin{array}{l}7 \\
3\end{array}$ \\
\hline \multicolumn{9}{|l|}{ Australian/south east Asian taxa } \\
\hline Psychopsis barnardi & 0 & 1 & 1 & 0 & - & - & 0 & - \\
\hline Psychopsis margarita & 0 & 1 & 1 & 0 & - & - & 0 & - \\
\hline Balmes birmanus & 1 & 1 & 1 & 0 & - & - & 0 & - \\
\hline Balmes terissinus & 1 & 1 & 1 & 0 & - & - & 0 & - \\
\hline \multicolumn{9}{|l|}{ Afrotropical taxa } \\
\hline Cabralis gloriosus & 0 & 1 & 1 & 0 & - & - & 0 & - \\
\hline Cabralis puritus & 0 & 1 & 1 & 0 & - & - & 0 & - \\
\hline Zygophlebius leoninus & 0 & 1 & 2 & 1 & 1 & 0 & 1 & 1 \\
\hline Zygophlebius zebra & 0 & 1 & 2 & 1 & 1 & 0 & 1 & 0 \\
\hline Zygophlebius pseudosilveira & 0 & 1 & 0 & 1 & 1 & $\overline{0}$ & 1 & 2 \\
\hline Silveira jordani & 0 & 1 & 2 & 0 & - & - & 0 & - \\
\hline Silveira rufus & 0 & 1 & 3 & 1 & 2 & 0 & 0 & - \\
\hline Silveira occultus & 0 & 1 & 3 & 1 & 0 & 1 & 0 & - \\
\hline Silveira marshalli & 0 & 1 & 3 & 1 & 0 & 0 & 0 & - \\
\hline \multicolumn{9}{|l|}{ Outgroup taxa } \\
\hline Polystoechotes punctatus & 0 & 0 & - & - & - & - & 0 & - \\
\hline Notiobiella viridis & 0 & 0 & - & - & - & - & 0 & - \\
\hline Apochrysa lutea & 0 & 0 & - & - & - & - & 0 & - \\
\hline Ithone fulva & 0 & 0 & - & - & - & - & 0 & - \\
\hline Nymphes myrmeleonides & 0 & 0 & - & - & - & - & 0 & - \\
\hline Libelloides rhomboideus & 0 & 0 & - & - & - & $\overline{7}$ & 0 & - \\
\hline Nemoptera coa & 0 & 0 & - & - & - & - & 0 & - \\
\hline Osmylops armatus & 0 & 0 & - & - & - & - & 1 & 2 \\
\hline Ululodes quadripunctatus & 0 & 0 & 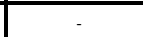 & 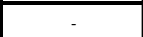 & 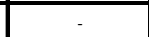 & - & 0 & - \\
\hline
\end{tabular}


Table S2: Matrix of morphological characters and states used in the study

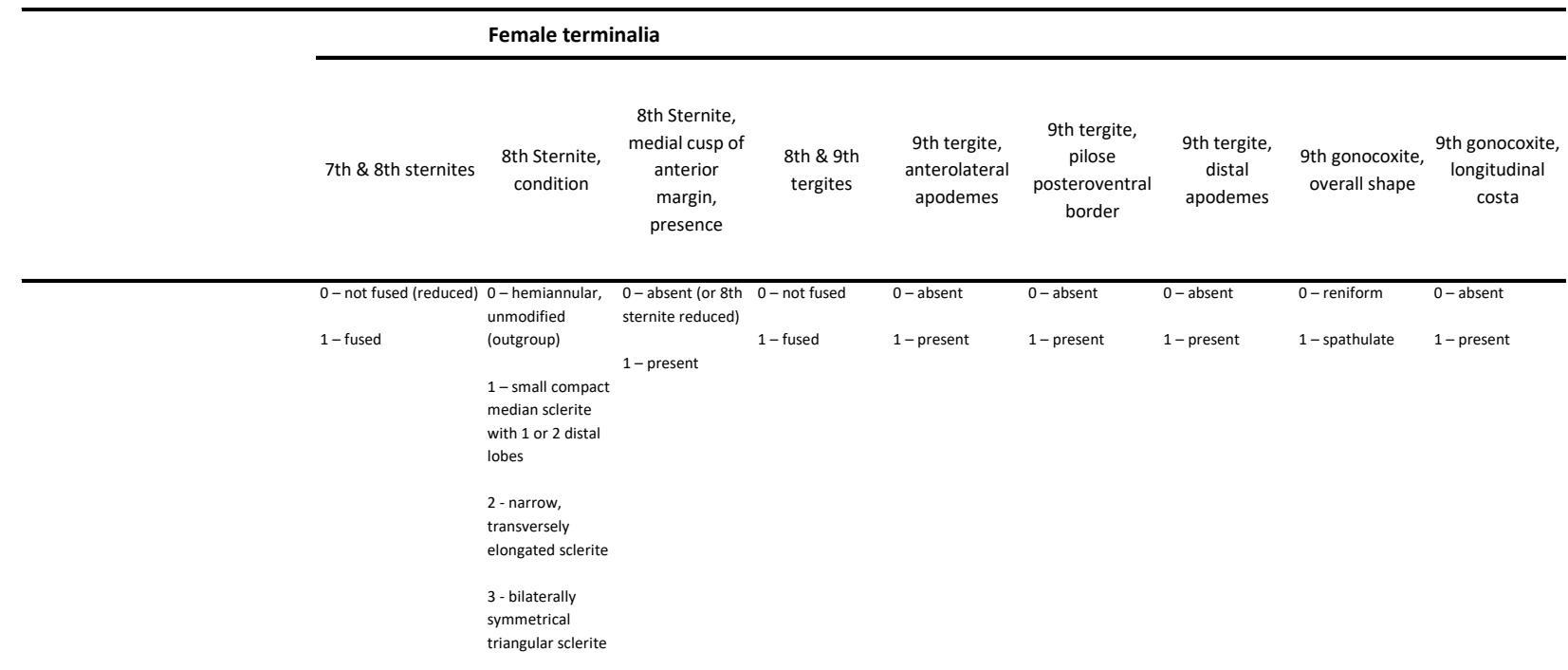

\begin{tabular}{|c|c|c|c|c|c|c|c|c|c|}
\hline & $\begin{array}{l}7 \\
4\end{array}$ & $\begin{array}{l}7 \\
5\end{array}$ & $\begin{array}{l}7 \\
6\end{array}$ & $\begin{array}{l}7 \\
7\end{array}$ & $\begin{array}{l}7 \\
8\end{array}$ & $\begin{array}{l}7 \\
9\end{array}$ & $\begin{array}{l}8 \\
0\end{array}$ & $\begin{array}{l}8 \\
1\end{array}$ & $\begin{array}{l}8 \\
2\end{array}$ \\
\hline \multicolumn{10}{|l|}{ Australian/south east Asian taxa } \\
\hline Psychopsis barnardi & 0 & 3 & 1 & 1 & 1 & 1 & 1 & 1 & 1 \\
\hline Psychopsis margarita & 0 & 3 & 1 & 1 & 1 & 1 & 1 & 1 & 1 \\
\hline Balmes birmanus & 1 & 2 & 0 & 1 & 1 & 1 & 1 & 1 & 1 \\
\hline Balmes terissinus & 1 & 2 & 0 & 1 & 1 & 1 & 1 & 1 & 1 \\
\hline \multicolumn{10}{|l|}{ Afrotropical taxa } \\
\hline Cabralis gloriosus & 0 & 1 & 0 & 1 & 1 & 1 & 1 & 1 & 1 \\
\hline Cabralis puritus & 0 & 1 & 0 & 1 & 1 & 1 & 1 & 1 & 1 \\
\hline Zygophlebius leoninus & 0 & 1 & 0 & 1 & 1 & 1 & 1 & 1 & 1 \\
\hline Zygophlebius zebra & 0 & 1 & 0 & 1 & 1 & 1 & 1 & 1 & 1 \\
\hline Zygophlebius pseudosilveira & 0 & 1 & 0 & 1 & 1 & 1 & 1 & 1 & 1 \\
\hline Silveira jordani & 0 & 2 & 0 & 1 & 1 & 1 & 1 & 1 & 1 \\
\hline Silveira rufus & 0 & 2 & 0 & 1 & 1 & 1 & 1 & 1 & 1 \\
\hline Silveira occultus & 0 & 2 & 0 & 1 & 1 & 1 & 1 & 1 & 1 \\
\hline Silveira marshalli & 0 & 2 & 0 & 1 & 1 & 1 & 1 & 1 & 1 \\
\hline \multicolumn{10}{|l|}{ Outgroup taxa } \\
\hline Polystoechotes punctatus & 0 & 0 & 0 & 0 & 0 & 0 & 0 & 0 & 0 \\
\hline Notiobiella viridis & 0 & 0 & 0 & 0 & 0 & 0 & 0 & 0 & 0 \\
\hline Apochrysa lutea & 0 & 0 & 0 & 0 & 0 & 0 & 0 & 0 & 0 \\
\hline Ithone fulva & 0 & 0 & 0 & 0 & 0 & 0 & 0 & 0 & 0 \\
\hline Nymphes myrmeleonides & 0 & 0 & 0 & 0 & 0 & 0 & 0 & 0 & 1 \\
\hline Libelloides rhomboideus & 0 & 0 & 0 & 0 & 0 & 0 & 0 & 0 & 0 \\
\hline Nemoptera coa & 0 & 0 & 0 & 0 & 0 & 0 & 0 & 0 & 0 \\
\hline Osmylops armatus & 0 & 0 & 0 & 0 & 0 & 0 & 0 & 0 & 1 \\
\hline Ululodes quadripunctatus & 0 & 0 & 0 & 0 & 0 & 0 & 0 & 0 & 0 \\
\hline
\end{tabular}


Table S2: Matrix of morphological characters and states used in the study

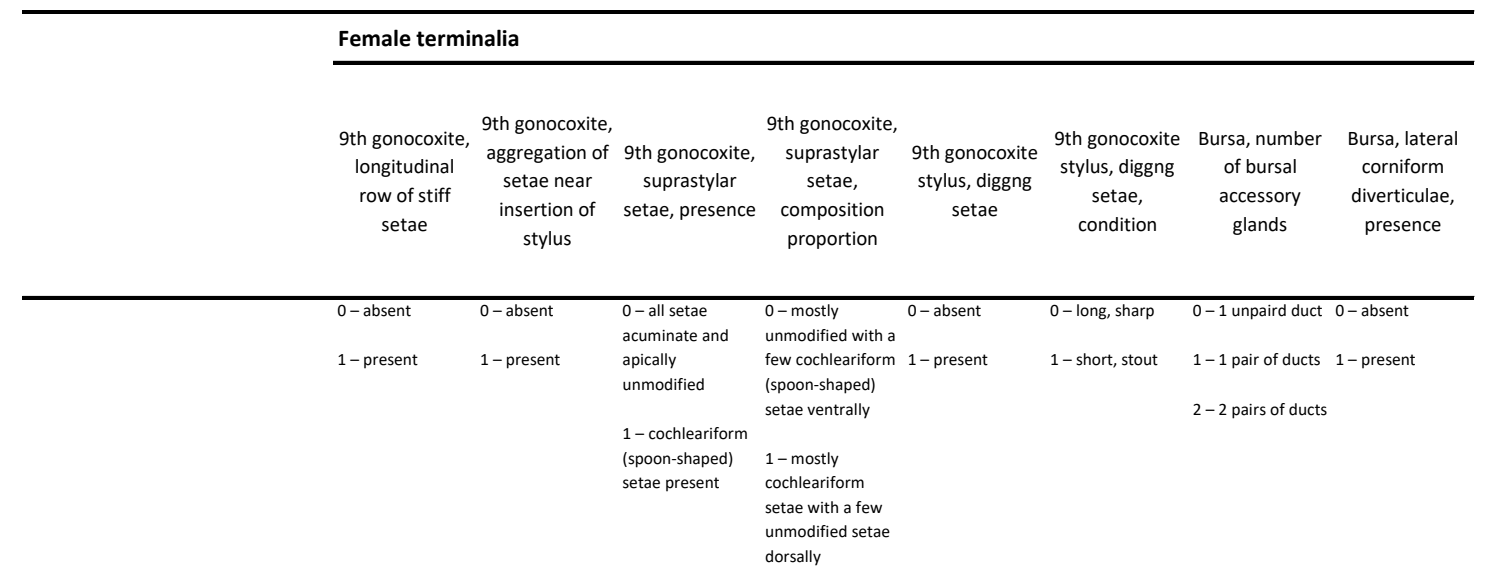

\begin{tabular}{|c|c|c|c|c|c|c|c|c|}
\hline & $\begin{array}{l}8 \\
3\end{array}$ & $\begin{array}{l}8 \\
4\end{array}$ & $\begin{array}{l}8 \\
5\end{array}$ & $\begin{array}{l}8 \\
6\end{array}$ & $\begin{array}{l}8 \\
7\end{array}$ & $\begin{array}{l}8 \\
8\end{array}$ & $\begin{array}{l}8 \\
9\end{array}$ & $\begin{array}{l}9 \\
0\end{array}$ \\
\hline \multicolumn{9}{|l|}{ Australian/south east Asian taxa } \\
\hline Psychopsis barnardi & 0 & 1 & 1 & 1 & 1 & 1 & 1 & 0 \\
\hline Psychopsis margarita & 0 & 1 & 1 & 1 & 1 & 1 & 1 & 0 \\
\hline Balmes birmanus & 0 & 0 & 1 & 1 & 1 & 1 & 0 & 0 \\
\hline Balmes terissinus & 0 & 0 & 1 & 1 & 1 & 1 & 1 & 0 \\
\hline \multicolumn{9}{|l|}{ Afrotropical taxa } \\
\hline Cabralis gloriosus & 0 & 0 & 1 & 1 & 1 & 1 & 1 & 1 \\
\hline Cabralis puritus & 0 & 0 & 1 & 1 & 1 & 1 & 1 & 1 \\
\hline Zygophlebius leoninus & 0 & 0 & 1 & 1 & 1 & 1 & 2 & 1 \\
\hline Zygophlebius zebra & 0 & 0 & 1 & 1 & 1 & 1 & 2 & 1 \\
\hline Zygophlebius pseudosilveira & 0 & 0 & 1 & 1 & 1 & 1 & 1 & 1 \\
\hline Silveira jordani & 1 & 0 & 1 & 0 & 1 & 0 & 1 & 0 \\
\hline Silveira rufus & 1 & 0 & 1 & 0 & 1 & 0 & 1 & 0 \\
\hline Silveira occultus & 1 & 0 & 1 & 0 & 1 & 0 & 1 & 0 \\
\hline Silveira marshalli & 1 & 0 & 1 & 0 & 1 & 0 & 1 & 0 \\
\hline \multicolumn{9}{|l|}{ Outgroup taxa } \\
\hline Polystoechotes punctatus & 0 & 0 & 0 & - & 0 & - & 1 & 0 \\
\hline Notiobiella viridis & 0 & 0 & 0 & - & 0 & - & 1 & 0 \\
\hline Apochrysa lutea & 0 & 0 & 0 & - & 0 & - & 1 & 0 \\
\hline Ithone fulva & 0 & 0 & 0 & - & 0 & - & 1 & 0 \\
\hline Nymphes myrmeleonides & 0 & 0 & 0 & - & 0 & - & 1 & 0 \\
\hline Libelloides rhomboideus & 0 & 0 & 0 & - & 0 & - & 0 & 0 \\
\hline Nemoptera coa & 0 & 0 & 0 & - & 0 & - & 0 & 0 \\
\hline Osmylops armatus & 0 & 0 & 0 & - & 0 & - & 1 & 0 \\
\hline Ululodes quadripunctatus & 0 & 0 & 0 & - & 0 & - & 0 & 0 \\
\hline
\end{tabular}


Table S2: Matrix of morphological characters and states used in the study

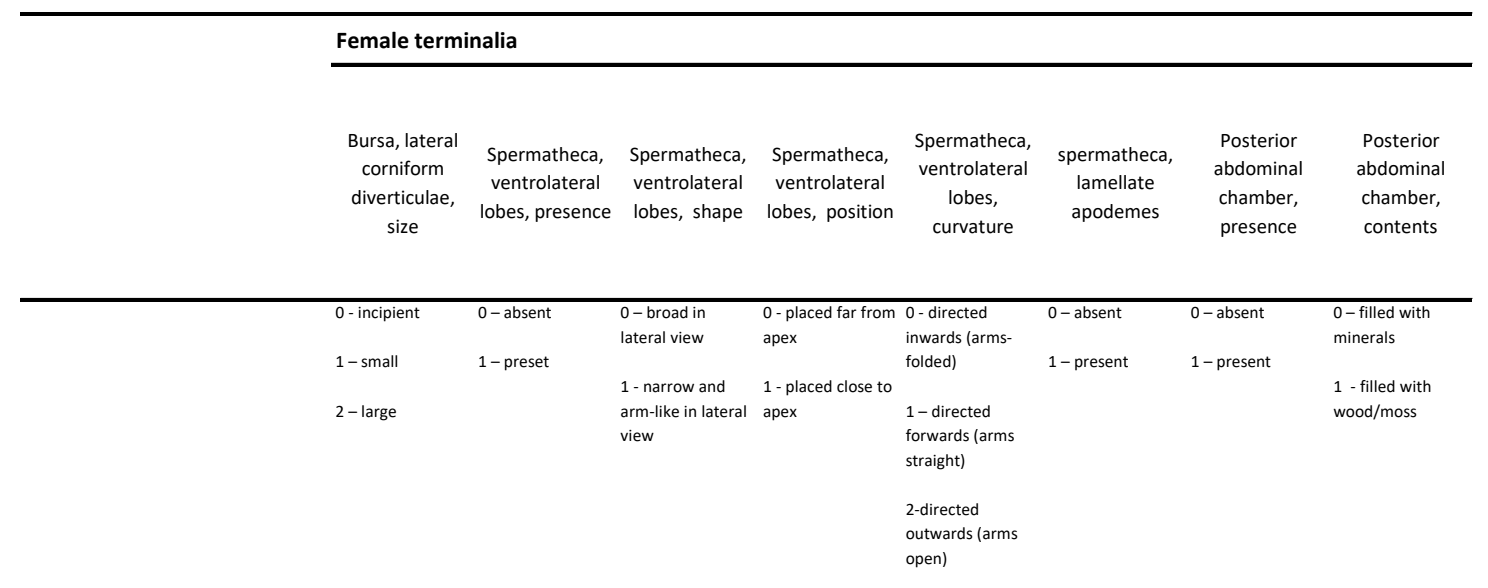

\begin{tabular}{|c|c|c|c|c|c|c|c|c|}
\hline & $\begin{array}{l}9 \\
1\end{array}$ & $\begin{array}{l}9 \\
2\end{array}$ & $\begin{array}{l}9 \\
3\end{array}$ & $\begin{array}{l}9 \\
4\end{array}$ & $\begin{array}{l}9 \\
5\end{array}$ & $\begin{array}{l}9 \\
6\end{array}$ & $\begin{array}{l}9 \\
7\end{array}$ & $\begin{array}{l}9 \\
8\end{array}$ \\
\hline \multicolumn{9}{|l|}{ Australian/south east Asian taxa } \\
\hline Psychopsis barnardi & - & 0 & - & - & - & 1 & 1 & 1 \\
\hline Psychopsis margarita & - & 0 & - & - & - & 1 & 1 & 1 \\
\hline Balmes birmanus & - & 0 & - & - & - & 0 & 1 & 1 \\
\hline Balmes terissinus & - & 0 & - & - & - & 0 & 1 & 1 \\
\hline \multicolumn{9}{|l|}{ Afrotropical taxa } \\
\hline Cabralis gloriosus & 0 & 1 & 0 & 0 & - & 0 & 1 & 1 \\
\hline Cabralis puritus & 0 & 1 & 0 & 0 & - & 0 & 1 & 1 \\
\hline Zygophlebius leoninus & 2 & 1 & 0 & 0 & - & 0 & 1 & 1 \\
\hline Zygophlebius zebra & 2 & 1 & 0 & 0 & - & 0 & 1 & 1 \\
\hline Zygophlebius pseudosilveira & 1 & 1 & 0 & 0 & - & 0 & 1 & 1 \\
\hline Silveira jordani & - & 1 & 1 & 0 & 2 & 0 & 1 & 0 \\
\hline Silveira rufus & - & 1 & 1 & 0 & 2 & 0 & 1 & 0 \\
\hline Silveira occultus & - & 1 & 1 & 1 & 0 & 0 & 1 & 0 \\
\hline Silveira marshalli & - & 1 & 1 & 0 & 1 & 0 & 1 & 0 \\
\hline \multicolumn{9}{|l|}{ Outgroup taxa } \\
\hline Polystoechotes punctatus & - & 0 & - & - & - & 0 & 0 & - \\
\hline Notiobiella viridis & - & 0 & - & - & - & 0 & 0 & - \\
\hline Apochrysa lutea & - & 0 & - & - & - & 0 & 0 & - \\
\hline Ithone fulva & - & 0 & - & - & - & 0 & 0 & - \\
\hline Nymphes myrmeleonides & - & 0 & - & - & - & 0 & 0 & - \\
\hline Libelloides rhomboideus & - & 0 & - & - & - & 0 & 0 & - \\
\hline Nemoptera coa & - & 0 & - & - & - & 0 & 0 & - \\
\hline Osmylops armatus & - & 0 & - & - & - & 0 & 0 & - \\
\hline Ululodes quadripunctatus & - & 0 & - & - & - & 0 & 0 & - \\
\hline
\end{tabular}


Table S3. Table showing primer sequences and cycling parameters used in this study.

\begin{tabular}{|c|c|c|c|c|c|}
\hline Gene & Primer & Direction & Primer sequence (5'-> 3') & Reference & Cycling Parameters \\
\hline $16 S$ & $\begin{array}{l}\text { LR-J-12887 } \\
\text { LR-N-13398 }\end{array}$ & $\begin{array}{l}\text { forward } \\
\text { reverse }\end{array}$ & $\begin{array}{l}\text { CCG GTC TGA ACT CAG ATC ACG T } \\
\text { CGC CTG TTT AAC AAA AAC AT }\end{array}$ & $\begin{array}{l}\text { Simon et al. } \\
1994\end{array}$ & $\begin{array}{l}\text { Initial denaturation: } 95^{\circ} \mathrm{C} \\
\text { (5min); } 33 \text { cycles of } 93^{\circ} \mathrm{C} \\
(20 \mathrm{~s}), 50 \pm 2^{\circ} \mathrm{C}(40 \mathrm{~s}), 72^{\circ} \mathrm{C} \\
(2 \mathrm{~min}) \text {; final elongation: } \\
72^{\circ} \mathrm{C} \text { (5min) }\end{array}$ \\
\hline $18 S$ & $\begin{array}{l}\text { 18S-intfw-ST12 } \\
\text { 18S-rev1 }\end{array}$ & $\begin{array}{l}\text { forward } \\
\text { reverse }\end{array}$ & $\begin{array}{l}\text { ATC AAG AAC GAA AGT TAG AG } \\
\text { ATG GGG AAC AAT TGC AAG C }\end{array}$ & $\begin{array}{l}\text { Simon et al. } \\
1994\end{array}$ & $\begin{array}{c}\text { Initial denaturation: } 94^{\circ} \mathrm{C} \\
(2 \mathrm{~min}) ; 30 \text { cycles of } 95^{\circ} \mathrm{C} \\
(10 \mathrm{~s}), 48 \pm 2^{\circ} \mathrm{C}(10 \mathrm{~s}), 7^{\circ} \mathrm{C} \\
(1 \mathrm{~min}) ; \text { final elongation: } \\
72^{\circ} \mathrm{C} \text { (5min) }\end{array}$ \\
\hline $\mathrm{COI}$ & $\begin{array}{l}\text { C1-J-2183 } \\
\text { TL2-N-3014 }\end{array}$ & $\begin{array}{l}\text { forward } \\
\text { reverse }\end{array}$ & $\begin{array}{l}\text { CAA CAT TTA TTT TGA TTT TTT GG } \\
\text { TCC AAT GCA CTA ATC TGC CAT ATT A }\end{array}$ & $\begin{array}{l}\text { Simon et al. } \\
1994\end{array}$ & $\begin{array}{l}\text { Initial denaturation: } 95^{\circ} \mathrm{C} \\
(5 \mathrm{~min}) ; 33 \text { cycles of } 93^{\circ} \mathrm{C} \\
(20 \mathrm{~s}), 50 \pm 2^{\circ} \mathrm{C}(40 \mathrm{~s}), 72^{\circ} \mathrm{C} \\
(2 \mathrm{~min}) ; \text { final elongation: } \\
72^{\circ} \mathrm{C} \text { (5min) }\end{array}$ \\
\hline \multirow[t]{2}{*}{ CAD } & $\begin{array}{l}581 \mathrm{~F} 2 \\
1098 \mathrm{r}\end{array}$ & $\begin{array}{l}\text { forward } \\
\text { reverse }\end{array}$ & $\begin{array}{c}\text { GGW GGW CAA ACW GCW YTM AAY TGY GG } \\
\text { TTN GGN AGY TGN CCN CCC AT }\end{array}$ & $\begin{array}{l}\text { Moulton \& } \\
\text { Wiegmann } \\
2004\end{array}$ & $\begin{array}{c}\text { Initial denaturation: } 94^{\circ} \mathrm{C} \\
(4 \mathrm{~min}) ;\left[4 \text { cycles of } 94^{\circ} \mathrm{C}\right. \\
(30 \mathrm{~s}), 51 \pm 2^{\circ} \mathrm{C}(30 \mathrm{~s}), 72^{\circ} \mathrm{C} \\
(2 \mathrm{~min})],\left[6 \mathrm{cycles} \text { of } 94^{\circ} \mathrm{C}\right. \\
(30 \mathrm{~s}), 47 \pm 2^{\circ} \mathrm{C}(1 \mathrm{~min}), \\
\left.72^{\circ} \mathrm{C}(2 \mathrm{~min})\right],[36 \text { cycles of } \\
94^{\circ} \mathrm{C}(30 \mathrm{~s}), 42 \pm 2^{\circ} \mathrm{C}(20 \mathrm{~s}), \\
\left.72^{\circ} \mathrm{C}(2: 30 \mathrm{~min})\right] \text {; final } \\
\text { elongation: } 72^{\circ} \mathrm{C}(3 \mathrm{~min})\end{array}$ \\
\hline & $\begin{array}{c}787 f \\
1278 r\end{array}$ & $\begin{array}{l}\text { forward } \\
\text { reverse }\end{array}$ & $\begin{array}{l}\text { GGD GTN ACN ACN GCN TGY TTY GAR CC } \\
\text { TCR TTN TTY TTW GCR ATY AAY TGC AT }\end{array}$ & $\begin{array}{l}\text { Moulton \& } \\
\text { Wiegmann } \\
2004\end{array}$ & $\begin{array}{c}\text { Initial denaturation: } 94^{\circ} \mathrm{C} \\
(4 \mathrm{~min}) ;\left[4 \text { cycles of } 94^{\circ} \mathrm{C}\right. \\
(30 \mathrm{~s}), 51 \pm 2^{\circ} \mathrm{C}(30 \mathrm{~s}), 72^{\circ} \mathrm{C} \\
(2 \mathrm{~min})],\left[6 \text { cycles of } 94^{\circ} \mathrm{C}\right. \\
(30 \mathrm{~s}), 47 \pm 2^{\circ} \mathrm{C}(1 \mathrm{~min}), \\
\left.72^{\circ} \mathrm{C}(2 \mathrm{~min})\right],[36 \text { cycles of } \\
94^{\circ} \mathrm{C}(30 \mathrm{~s}), 42 \pm 2^{\circ} \mathrm{C}(20 \mathrm{~s}), \\
\left.72^{\circ} \mathrm{C}(2: 30 \mathrm{~min})\right] \text {; final } \\
\text { elongation: } 72^{\circ} \mathrm{C}(3 \mathrm{~min})\end{array}$ \\
\hline
\end{tabular}


Table S4. Model parameters used in maximum likelihood, Bayesian and divergence time estimates analyses (above), and sequencing information for each gene partition (below).

\begin{tabular}{ccccc}
\hline Parameter & $16 S$ & $18 S$ & COI & CAD \\
\hline Best-fit model (AIC) & GTR+l+G & TVM+l+G & TIM2+I+G & TIM3+l+G \\
A frequency & 0.3972 & 0.2245 & 0.3089 & 0.3596 \\
C frequency & 0.1267 & 0.2009 & 0.1114 & 0.1348 \\
G frequency & 0.0831 & 0.2780 & 0.1375 & 0.1772 \\
T frequency & 0.3931 & 0.2966 & 0.4422 & 0.3284 \\
Gamma shape & 1.1010 & 0.3110 & 1.1410 & 0.3570 \\
p-inv & 0.4120 & 0.4740 & 0.5580 & 0.2120 \\
Base pairs & $\approx 450$ & $\approx 1006$ & 747 & 1543 \\
Conserved sites & 242 & 628 & 493 & 910 \\
Parsimony-informative & 150 & 166 & 202 & 478 \\
sites & & & & \\
\hline
\end{tabular}


Table S5. Model parameters used in ancestral area estimation analysis.

\begin{tabular}{|c|c|c|c|}
\hline $\begin{array}{c}\text { Analysis } \\
\text { model }\end{array}$ & Data Input & Areas & Range Constraints \\
\hline S-DIVA & $\begin{array}{c}15000 \text { trees + } \\
1 \text { condensed } \\
\text { tree (from } \\
\text { BEAST) }\end{array}$ & $\begin{array}{l}\text { A: Australia } \\
\text { B: SE Africa } \\
\text { C: SW Africa } \\
\text { D: SE Asia }\end{array}$ & $\begin{array}{c}\text { All ranges checked in ancestral range matrix. Max areas }=2 . \\
\text { Extinction allowed. }\end{array}$ \\
\hline BayArea & $\begin{array}{l}1 \text { condensed } \\
\text { tree (from } \\
\text { BEAST) }\end{array}$ & $\begin{array}{l}\text { A: }-20.9175,142.7027 \\
\text { B: }-23.8320,30.1358 \\
\text { C: }-23.5618,15.3041 \\
\text { D: } 24.8801,102.8329\end{array}$ & $\begin{array}{c}\text { Geodistance power }=\text { True } \\
\text { Chain length } 500000000 \text { sampling every } 1000^{\text {th }} \text { iteration }\end{array}$ \\
\hline
\end{tabular}

